\title{
SPREADING THE WORD: CAPITAL MARKET CONSEQUENCES OF BUSINESS PRESS COVERAGE OF MANAGEMENT EARNINGS GUIDANCE
}

\author{
A Dissertation \\ by \\ BRADY J. TWEDT \\ Submitted to the Office of Graduate Studies of \\ Texas A\&M University \\ in partial fulfillment of the requirements for the degree of \\ DOCTOR OF PHILOSOPHY
}

$\begin{array}{ll}\text { Chair of Committee, } & \text { Lynn Rees } \\ \text { Committee Members, } & \text { Senyo Tse } \\ & \text { Nathan Sharp } \\ & \text { Scott Lee } \\ \text { Head of Department, } & \text { James Benjamin }\end{array}$

August 2013

Major Subject: Accounting

Copyright 2013 Brady J. Twedt 


\begin{abstract}
This study investigates the role of the business press in disseminating management earnings guidance news to capital market participants. Using a unique sample of over 55,000 articles that relate specifically to management guidance, I find that 48 percent of all guidance receives coverage in the business press, with substantial within-firm variation. I then identify firm and guidance characteristics that are associated with the likelihood that guidance receives press coverage. Controlling for the endogeneity of press coverage, I find that dissemination in the press has a significant impact on the market reaction to guidance, and this effect is economically large. This study is the first to provide evidence that there is systematic variation in the extent to which guidance news is disseminated through the press, and that this variation has a significant effect on the market consequences of guidance.
\end{abstract}




\section{ACKNOWLEDGEMENTS}

I am indebted to my dissertation committee, Lynn Rees (chair), Senyo Tse, Nathan Sharp, and Scott Lee for their suggestions and insights. I thank Steve Baginski, Linda Bamber, Andy Call, Mike Drake, Travis Dyer, Jared Jennings, Stephannie Larocque, Dongyoung Lee, Tom Omer, Jake Thornock, Ram Venkataraman (the CFEA discussant), Jaron Wilde, Chris Wolfe, and seminar participants at the 2012 Conference on Financial Economics and Accounting (CFEA), Arizona State University, Brigham Young University, Indiana University, Rice University, Southern Methodist University, Texas A\&M University, University of Georgia, University of Illinois, University of Notre Dame, University of Texas at Dallas, University of Washington, and Washington University in St. Louis for their comments.

I also thank RavenPack, Inc., as well as Jonathan Rogers and Andrew Van Buskirk, for providing data to support this project. Finally, I appreciate Steve Jones (Dow Jones Newswires), Ben Worthen (The Wall Street Journal), Andrew Edgecliffe-Johnson (Financial Times), and Malcolm Bain (RavenPack) for helpful discussions that increased my understanding of the business press. 


\section{TABLE OF CONTENTS}

Page

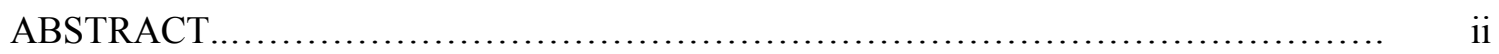

ACKNOWLEDGEMENTS..................................................... iii

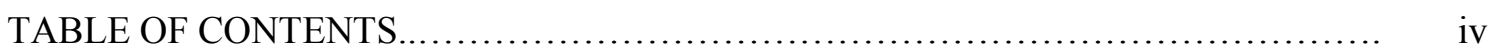

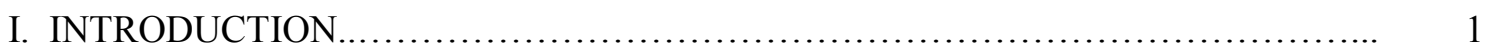

II. HYPOTHESES DEVELOPMENT ............................................ 7

III. SAMPLE SELECTION AND COMPOSITION ................................. 11

IV. DETERMINANTS OF GUIDANCE PRESS COVERAGE....................... 15

4.1 Research Method.................................................... 15

4.2 Empirical Results.................................................... 18

V. MARKET REACTION TO GUIDANCE PRESS COVERAGE....................... 21

5.1 Research Method...................................................... 21

5.2 Matched Samples.................................................... 23

5.3 Empirical Results................................................. 25

VI. ADDITIONAL ANALYSES ................................................ 28

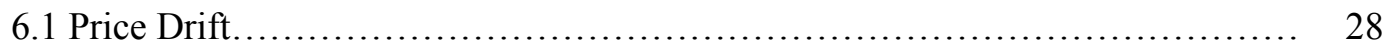

6.2 Long-Window Returns Portfolios....................................... 29

6.3 Comparison of Stand-Alone and Bundled Guidance ........................ 31

6.4 Heckman Selection Model................................................. 31

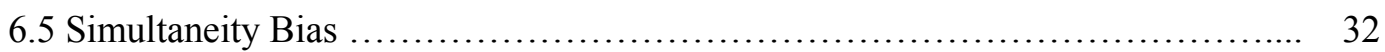

6.6 Alternative Empirical Measures ..................................... 34

VII. CONCLUSIONS......................................................... 36

REFERENCES............................................................ 38

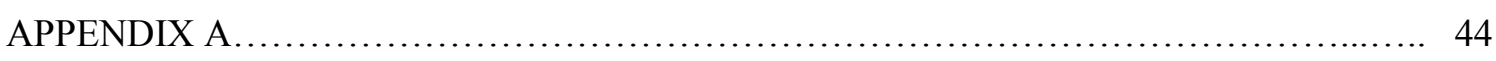

APPENDIX B............................................................. 59 


\section{INTRODUCTION}

Management earnings guidance is a primary means by which the market adjusts its expectations of firms' earnings performance (Penman 1980; Cotter et al. 2006; Beyer et al. 2010). ${ }^{1}$ One of the main reasons managers choose to issue earnings guidance is to reduce information asymmetry and align market expectations of firm performance with their own private information (Ajinkya and Gift 1984; King et al. 1990). However, the capital market consequences of issuing earnings guidance are dependent on the guidance being effectively communicated to the market. In this study, I examine the extent to which the business press facilitates this process by disseminating the information contained in management earnings guidance to market participants. I first identify firm and guidance characteristics that affect the likelihood that management guidance receives press coverage. I then examine the effects of guidance dissemination in the business press on market participants' reactions to the information contained in the guidance.

Empirical evidence of variation in guidance dissemination and the associated market effects can increase our understanding of how information flows from managers to the market and provide evidence on an important link between managers' voluntary actions and the effects of those actions. Prior research on management guidance provides extensive evidence that the market reacts to the magnitude of the earnings news in the guidance as well as the credibility of the guidance (e.g., Jennings 1987; Hutton and Stocken 2009; Yang 2012). Implied in most studies is the assumption that the extent of guidance dissemination, or the timing and degree to which market participants are made aware of the guidance, is irrelevant. I propose that the role of the business press in disseminating guidance news to the market is critical because earnings

\footnotetext{
${ }^{1}$ For example, Beyer et al. (2010) find that management earnings guidance provides 59 percent of all accounting-based information used by the market, while Cotter et al. (2006) report that 47 percent of analysts revise their forecasts within five days after guidance. Note that I use the terms "management earnings guidance" and "management earnings forecast" interchangeably throughout the paper.
} 
guidance disclosures are voluntary and typically unexpected (Doyle and Magilke 2012). I hypothesize that the market reaction to the information contained in management guidance is a function of the extent to which the guidance is disseminated to market participants.

My predictions are based on prior empirical studies that examine the effects of information dissemination in other settings and on theoretical models that are based on the limited attention and information processing power of individuals. Several recent empirical studies provide evidence that the extent and method by which information is disseminated to investors can significantly impact firms' information environments and stock prices. These studies examine various dissemination channels such as the business press (e.g., Bushee et al. 2010; Engelberg and Parsons 2011; Li et al. 2011), internet searches (Drake et al. 2012), social media (Blankespoor et al. 2013), and online financial message boards (Lerman 2011). Hirshleifer and Teoh (2003) and Bloomfield (2002) provide a theoretical basis for the notion that the manner in which information is communicated to investors is relevant to prices. Hirshleifer and Teoh (2003) develop a model in which informationally equivalent disclosures have different effects on investor perceptions, depending on how and where the information is presented. Bloomfield (2002) posits that, because press coverage substantially reduces information acquisition costs, the dissemination of disclosures in the press should be associated with greater price reactions to the information contained in the disclosures, a conjecture I explicitly test within the context of management earnings guidance.

The above empirical and theoretical evidence suggests that press coverage may have a significant effect on the capital market consequences of management guidance. However, a longheld assumption in capital markets research is that once a firm publicly discloses value-relevant information, it is instantaneously incorporated into prices, making the mechanism through which the information is disseminated to market participants irrelevant (Merton 1987). If sophisticated 
market participants such as institutional investors and financial analysts closely monitor the firms within their purview, they may not depend on the business press for information, particularly with respect to an important, value-relevant corporate disclosure such as earnings guidance (Beyer et al. 2010). In addition, numerous other mechanisms now exist that convey corporate disclosures to market participants; these include corporate websites, email alerts, social media, webcasts, broadcast media, and EDGAR (Blankespoor et al. 2013). Thus, whether press coverage has a significant effect on the pricing of guidance news is ultimately an empirical question.

I obtain management earnings guidance data from First Call and business press data from RavenPack. My sample of guidance consists of 66,598 management forecasts issued during the years 2001 to 2010 . RavenPack is a news analytics firm with a special partnership with Dow Jones (DJ). Through this partnership, RavenPack is able to provide access to the full DJ news archives, which consists of all DJ Newswire and Wall Street Journal (WSJ) articles. RavenPack provides information on the firm(s) to which the articles relate, the exact time the articles were published, and most importantly for the sake of this study, the news events to which the articles pertain. ${ }^{2}$ Because the focus of my analysis is on the information dissemination role of the business press, I use newswire articles alone to identify guidance press coverage (Soltes 2010; Li et al. 2011), although I utilize the full DJ news archives to measure control variables related to press coverage. Using those newswire articles identified by RavenPack as relating specifically to management earnings guidance, I classify 48 percent of the guidance observations in my sample as having received coverage in the business press. $^{3}$

\footnotetext{
${ }^{2}$ Refer to the concluding section of the paper for a discussion of the advantages and disadvantages associated with using the DJ news archives as a source of business press data. Also, Section 6 discusses results using an alternative source of business press articles.

${ }^{3}$ As a comparison, in untabulated analysis I find that 79 percent of all quarterly earnings announcements for my sample firms received coverage in the business press. This difference likely reflects the greater
} 
Using this unique measure of management earnings guidance press coverage, I first identify guidance and firm characteristics that are associated with the likelihood that guidance receives coverage in the business press. I find that guidance is more likely to receive press coverage when it contains more absolute earnings news, when it is a quarterly earnings forecast (as opposed to annual), when it is bundled with an earnings announcement, and when it is issued on a slower news day. I also find that firms with more prior press coverage, firms in a major stock index, and firms with higher levels of institutional ownership are more likely to receive guidance press coverage. Additionally, I find evidence of significant within-firm variation in guidance press coverage.

Next, I examine the effect of press coverage on investors' reaction to the earnings news provided by management guidance. If the dissemination of guidance information by the business press increases investor awareness, then guidance press coverage should be associated with a stronger price reaction to the earnings news contained in the guidance. Because press coverage is an endogenous choice made by reporters, I test this assertion using propensity-score and withinfirm matched sample research designs to control for factors that may affect both the likelihood of guidance receiving press coverage and the capital market consequences of that coverage. This research method allows me to more clearly attribute the observed market consequences to the press coverage itself, rather than to firm or guidance characteristics associated with press coverage. I find that guidance coverage in the business press is associated with a significant increase in the abnormal price reaction to guidance news. The economic effect of this result is significant: the price reaction to guidance news nearly doubles when the guidance receives press coverage. These results suggest that dissemination in the business press substantially affects how investors respond to management earnings guidance.

publicity and attention associated with earnings announcements relative to management guidance (Doyle and Magilke 2012). 
To provide further evidence on the role of the business press in disseminating guidance news to market participants, I examine the effect of guidance press coverage on financial analysts' reaction to the guidance. I find that press coverage is significantly positively associated with the percentage of analysts who revise their forecasts immediately following the issuance of the guidance. This finding provides the first empirical evidence that the forecasting decisions of financial analysts are influenced by the business press coverage of the firms they follow. Taken together, the above results suggest that the responses of both investors and financial analysts are significantly affected by guidance press coverage.

In additional analyses, I document differences in the timing of long-window return realizations for covered and non-covered guidance. I also find that the effect of press coverage is attenuated when guidance is issued concurrently with an earnings announcement due to the publicity typically associated with earnings announcements. Next, I provide evidence that suggests my results are not driven by endogeneity related to selection due to unobservable factors or simultaneity bias. Finally, I find that my results are robust to alternative measures of business press coverage and guidance earnings news.

The results of this study contribute to the literatures on management earnings guidance and the information dissemination role of the business press. Prior research on management earnings guidance has examined numerous capital market consequences of managers' forecasting decisions, including price responses, changes in information asymmetry, reputational effects, and changes in analysts' forecasting behavior (see Hirst et al. (2008) for a review of this literature). However, this research has not explored the variation or relevance of the dissemination of guidance news to market participants. This study is the first to provide evidence that there is systematic variation in the extent to which guidance information is disseminated, and that this variation has a significant effect on the market consequences of guidance. This 
evidence increases our understanding of the economic implications of firms' voluntary disclosure practices, which future research may need to consider. In addition, Bushee et al. (2010) call for research examining how managers can act to improve the dissemination of their disclosures by the press. Understanding the determinants of press coverage of management guidance is a useful step in this direction. Managers can use this information, as well as the evidence provided in this study regarding the market consequences of press coverage of earnings guidance, to determine appropriate voluntary disclosure strategies for their firms. 


\section{HYPOTHESES DEVELOPMENT}

Under the expectations-adjustment hypothesis, managers issue earnings guidance in order to align market expectations of firm performance with their own private information (Ajinkya and Gift 1984; King et al. 1990). The impounding of this private information into stock prices reduces information asymmetries in the market and provides firms with numerous potential benefits including a reduced cost of capital, lower investor transaction costs, lower stock price fluctuations, and better relations with analysts (Coller and Yohn 1997; Hutton and Stocken 2009; Feng and Koch 2010). However, managers' ability to successfully align market expectations with their own is contingent on the extent to which market participants incorporate the guidance into their belief revision and decision-making processes (Hirst et al. 2007; Feng and McVay 2010).

Beginning with Jennings (1987), prior research has generally taken the market reaction to management earnings guidance to be a function of the information contained in the guidance and the credibility (i.e., believability) of the guidance (e.g., Williams 1996; Mercer 2004; Yang 2012; Ng et al. 2013). Building on the findings of recent empirical and theoretical research in accounting and finance, I propose that the market reaction to guidance is also a function of the extent to which the guidance information is disseminated to market participants. Loosely adapted from the framework of Feng and Koch (2010), Figure 1 summarizes my framework for analyzing the market consequences of management guidance. In this setting, managers issue earnings guidance in order to align market expectations with their own private information. However, before market participants can evaluate the information content and credibility of the guidance, the information must first be brought to their attention.

Prior research examining the market consequences of management earnings guidance generally relies on the (typically implied) assumption of instantaneous information diffusion and 
efficient processing of publically available information by market participants. ${ }^{4}$ Under this assumption, the mechanism by which the information is disseminated to the market becomes irrelevant, and the market reaction is solely a function of the information content and credibility of the disclosure. However, the findings of recent studies suggest that the business press can play an economically significant role in disseminating information to investors. For example, Bushee et al. (2010) provide evidence that press coverage during earnings announcement periods reduces bid-ask spreads and improves market depths. Additionally, Li et al. (2011) document significant market reactions to newswire alerts related to previously publicly available $10-\mathrm{K}$ and 10-Q filings.

Although the business press is widely assumed to be the largest and most broadly disseminated source of corporate information (Fang and Peress 2009; Bushee et al. 2010), there are a number of alternative methods for market participants to obtain information regarding firm disclosures. ${ }^{5}$ Market participants can actively seek disclosure information through channels such as corporate websites, internet searches, and EDGAR; firms can "push" the information to users via direct-access information technologies such as RSS feeds, email alerts, or social media posts; and information can be provided by other sources including broadcast media and financial blogs. Recent research provides evidence that these other dissemination channels can also affect market activity. For example, Drake et al. (2012) find that the amount of effort expended by investors in obtaining company-specific financial news through Google searches has a significant impact on the price discovery process around earnings announcements, while Blankespoor et al. (2013)

\footnotetext{
${ }^{4}$ Refer to Bloomfield (2002), Merton (1987), Diamond (1985), and Grossman and Stiglitz (1980) for more information regarding this assumption. One prior management guidance study that does consider information dissemination is Bamber and Cheon (1998). They argue that guidance issued in press releases reach a broader audience than guidance issued in meetings with analysts or reporters. However, their discussion is in the context of the pre-Reg FD period, and they do not examine the capital market effects of these different venue choices.

${ }^{5}$ See Blankespoor et al. (2013) for a more detailed discussion of the various mechanisms that transmit disclosures to market participants, and Bushee et al. (2010) for a discussion of the role of the business press as an information intermediary.
} 
find that corporate postings on the social media site Twitter reduce bid-ask spreads and improve market depths.

The dissemination channel examined in this study is the business press, and the Dow Jones $(D J)$ Newswires in particular. Prior research has shown that the business press, in its role as an information intermediary, can have a substantial influence on market activity (e.g., Huberman and Regev 2001; Kothari et al. 2009b; Engelberg and Parsons 2011; Rees et al. 2012). Additionally, numerous prior studies have used DJ to measure firms' press coverage (e.g., Barber and Odean 2008; Tetlock 2010, 2011; Engelberg et al. 2012). Tetlock (2007) argues that the DJ Newswires are a natural choice for a business press data source that impacts the market, due to their large circulation and influence. Similarly, Chan $(2003,230)$ notes that, "by far the sources with the most complete coverage across time and stocks are the DJ Newswires. This source does not suffer from gaps in coverage, and it is the best approximation of public news for traders."

Under the framework proposed above, coverage in the business press increases market participants' awareness of the information provided in management earnings guidance, thereby enabling them to appropriately respond to the information content and credibility of the disclosure. Similar to the argument made in Barber and Odean (2008) regarding stock purchases, market participants must first be made aware of management guidance before they can respond to it. In the words of Barber and Odean $(2008,785)$, "preferences determine choices after attention has determined the choice set."

There is also theoretical support for the notion that the extent and method by which information is disseminated to the market can have economic implications. For example, the model presented in Hirshleifer and Teoh (2003) departs from the assumption in traditional disclosure models that investors are fully rational and capable of efficiently processing all 
relevant information. In their model, investors have limited attention and processing power, and must therefore allocate their attention on a cost-benefit basis, potentially neglecting valuerelevant information. Accordingly, information that is more easily obtained and processed will have a stronger impact on investor perceptions. ${ }^{6}$ A similar argument is made in Bloomfield (2002), who predicts that firm disclosures that are disseminated in the press should be associated with greater market reactions because dissemination in the business press represents an inverse measure of the costs of identifying and collecting relevant information. By reducing the information acquisition costs associated with searching for and processing firm news, the business press can increase the amount of information that is efficiently assimilated by market participants (Merton 1987).

Based on the above empirical and theoretical evidence, I hypothesize that market participants react more strongly to the information provided by management earnings guidance when the guidance receives coverage in the business press. To empirically test this proposition, I examine the responses of two key groups of market participants to press coverage of management guidance: investors and financial analysts. ${ }^{7}$ My primary hypothesis is stated in alternative form as follows:

$H_{1}$ : There is a positive relation between business press coverage of management earnings guidance and the market reaction to the information contained in the guidance.

\footnotetext{
${ }^{6}$ Referring to the problem that limited attention may cause investors to fail to identify and process some aspect of the economic environment correctly, Hirshleifer and Teoh $(2003,345)$ state that, "the problem can be ameliorated in part if an individual can hire an intermediary to pay attention on his behalf." This could implicitly occur when an investor subscribes to a business press publication.

${ }^{7}$ In addition to investors, analysts are a key consumer of management earnings guidance, and managers often issue guidance in order to influence analysts' expectations (Graham et al. 2005; Cotter et al. 2006). Evidence in prior research suggests that, similar to investors, analysts also have limited attention and processing power (Hirshleifer and Teoh 2003), and that their ability to process and react to information is affected by both the complexity of the information (Plumlee 2003; Bradshaw et al. 2009), as well as the manner in which the information is presented (Hirst and Hopkins 1998; Hopkins et al. 2000).
} 


\section{SAMPLE SELECTION AND COMPOSITION}

My sample of management earnings guidance is obtained from First Call's Company Issued Guidance (CIG) database. During my sample period of 2001 to 2010, the CIG database contains 89,725 unique quantitative (i.e., point or range) management forecasts of quarterly or annual earnings per share denoted in U.S. dollars. ${ }^{8}$ I remove guidance issued after the end of the forecasting period in order to focus on forecasts of earnings rather than pre-announcements of actual earnings (Hirst et al. 2008; Koch and Park 2011). I also eliminate guidance issued by firms without stock price and returns data available from CRSP and financial information available from Compustat, as well as guidance issued by firms without sufficient analyst coverage and actual earnings data. ${ }^{9}$ Of the 66,598 management earnings forecasts in my final sample, 9,286 are "stand-alone" forecasts, or management guidance that is not bundled with an earnings announcement or issued on the same day as another forecast by the same firm. The sample selection process is detailed in Panel A of Table 1.

My sample of business press articles comes from RavenPack, a news analytics firm. Through a unique partnership with Dow Jones (DJ), RavenPack is able to provide access to the full DJ news archives, which consists of all DJ Newswire and Wall Street Journal articles.

\footnotetext{
${ }^{8}$ Following prior literature, I exclude open-ended and qualitative guidance that does not provide a numerical value of earnings per share necessary to identify the earnings news contained in the guidance (e.g., Rogers and Stocken 2005; Hilary and Hsu 2011). Including open-ended guidance, where the upper/lower bound of the guidance is used to calculate guidance news, does not change my inferences. Chuk et al. (2013) identify several issues related to the coverage of the CIG database, particularly with regards to guidance issued prior to the enactment of Reg FD, and guidance issued by firms without analyst coverage. These issues are not a concern in my study as I focus on the post-Reg FD period and I require analyst coverage. Further, I do not compare firms that issue guidance to those that do not, which eliminates the need to make any assumptions about firms not found in the CIG database.

${ }^{9}$ I require the issuance of earnings forecasts by at least two unique analysts within 90 days prior to the guidance date in order to calculate guidance earnings news, as described in the following section. Additionally, I eliminate guidance issued by firms with a stock price lower than $\$ 2.00$ in order to mitigate the small denominator problem. Including pre-announcements and guidance issued by firms with an analyst following of one or a stock price lower than $\$ 2.00$ does not affect my inferences. Results are also robust to including only quarterly or annual guidance in the regressions separately, as well as eliminating financial services and utility firms from the sample.
} 
During my sample period of 2001 to 2010 , the DJ news archives contain roughly 24.7 million articles. In addition to providing information on the firm(s) the articles relate to and the exact time the articles were published, RavenPack uses proprietary algorithms to identify the news events to which the articles pertain. ${ }^{10}$

Although I use the full sample of business press articles in calculating several of my control variables (discussed in the following sections), my primary interest lies in newswire articles that relate specifically to management earnings guidance. I use newswire articles alone to identify guidance press coverage because the focus of my analysis is on the information dissemination role of the business press (Soltes 2010; Li et al. 2011). During my sample period of 2001 to 2010, there are 55,971 DJ Newswires articles identified by RavenPack as relating to management earnings guidance. I code management guidance as receiving coverage in the business press if there was a guidance-related article written about the firm on the same day that the guidance was announced by the firm (day t). ${ }^{11}$ Using this methodology, I classify 31,955 of the 66,598 management forecasts in my final sample as having received press coverage.

One potential concern with this approach to identifying whether or not management earnings guidance received coverage in the business press is that if many of the guidance-related articles were published in the days following day $\mathrm{t}$, rather than on the date the guidance was

\footnotetext{
${ }^{10}$ RavenPack provides ISIN firm identifiers, which enables their data to be easily merged with Compustat and other commonly used databases. RavenPack also provides a relevance score (0 to 100$)$, which indicates the relevance of the article to the company. Any article with an event category (i.e. management earnings guidance) assigned to it by definition has a relevance score of 100. Based on discussions with RavenPack representatives, I require a relevance score of 90 or above for my control variables that are not based on a specific event category. I also remove press releases, articles designated by RavenPack as "Tabular Material", and any articles relating to equity market trade imbalances from my sample. Relaxing these restrictions does not affect my results.

${ }^{11}$ I use an indicator variable equal to one if there were one or more guidance-related articles published on the day the guidance was announced, rather than a count of the number of articles. Newswires often issue multiple updates within a short period of time, but these updates are unlikely to further disseminate the original information (Soltes 2010). The use of an indicator variable is consistent with prior research (e.g., Barber and Odean 2008; Tetlock 2010; Engelberg et al. 2012), although I find similar results using a count of the number of articles. Also, Solomon and Soltes (2012) note that a one-day window is appropriate when measuring press coverage of an earnings event.
} 
announced, or if the dates in the RavenPack and CIG databases are misaligned, then my measure of guidance press coverage could contain measurement error. To address this concern, Figure 2 provides a mapping of the guidance-related article dates from RavenPack into the guidance issuance dates from the CIG database. I find that of the 66,598 management forecasts in my sample, 31,955 have press coverage on day t, while only 502 management forecasts are classified as having press coverage on any of the six days surrounding day t. This evidence suggests that my measure is accurately capturing guidance press coverage.

To provide some descriptive evidence regarding the composition of my sample, Panels $\mathrm{B}, \mathrm{C}$, and $\mathrm{D}$, of Table 1 present the distribution of the sample across years, industries, and weekdays, respectively. As shown in Panel B of Table 1, the guidance observations are relatively evenly distributed throughout the sample period, with an average of 6,660 observations per year. Additionally, $47.9 \%$ of the guidance in my sample received press coverage, while, on average, $64.8 \%$ of my sample firms received at least some guidance press coverage during a given year. Panel C of Table 1 presents the composition of the sample across industries. Although there are differences in press coverage across industries, these differences do not appear to be substantial, with the percentage of guidance receiving coverage ranging from a low of $39.4 \%$ in the telecom industry to a high of $57.3 \%$ in the chemical industry. As shown in Panel D of Table 1, guidance is most frequently issued on Thursdays, with far fewer announcements made on Mondays and Fridays. However, the percentage of guidance receiving press coverage is relatively consistent across the different days of the week, ranging from $46.0 \%$ on Tuesdays to $49.6 \%$ on Thursdays.

Finally, Figure 3 provides an examination of the within-firm variation in guidance press coverage. There are 2,914 unique firms in my sample, of which 1,939 received guidance press coverage at least once during my sample period of 2001 to 2010 . For these 1,939 firms, I identify the percentage of their guidance issued during this time that received press coverage, and call 
this variable Press_Cover_\%. A firm whose guidance always (50\% of the time) received press coverage would have a value of Press_Cover_\% equal to 1.0 (0.5). The distribution of Press_Cover_\% thus captures the degree of within-firm variation in guidance press coverage in my sample. As shown in Figure 3, there is substantial variation in within-firm guidance press coverage, as $50 \%$ of the firms that received some guidance press coverage received it for less than $60 \%$ of their guidance (median $=0.56$ ), and less than $10 \%$ of these firms received guidance press coverage for $90 \%$ or more of their guidance $\left(90^{\text {th }}\right.$ percentile $\left.=0.87\right)$. This suggests that it is more than characteristics of the firm itself that determine guidance press coverage, and thus motivates the inclusion of guidance characteristics in the determinants of coverage analysis discussed in the following section. 


\section{DETERMINANTS OF GUIDANCE PRESS COVERAGE}

\subsection{Research Method}

The first stage of my analyses is an examination of the factors that determine business press coverage of management earnings guidance. Because the coverage decisions of the press are not exogenous (Bushee et al. 2010), it is important to control for these factors in my subsequent analyses. To provide evidence on the determinants of guidance press coverage, I estimate the following pooled cross-sectional logistic regression with standard errors clustered by firm: ${ }^{12}$

$$
\begin{aligned}
& \text { Press_Cover }=\alpha+\beta_{1} \text { Abs_Guide_News }+\beta_{2} \text { Bad_Guide_News }+\beta_{3} \text { Guide_Reputation (1) } \\
& +\beta_{4} \text { Annual }+\beta_{5} \text { Horizon }+\beta_{6} \text { Range }+\beta_{7} \text { Bundled }+\beta_{8} \text { Multiple }+ \text { P_Guide_Press_Cover } \\
& +\beta_{10} \mathrm{P} \_ \text {Month_Press_Cover }+\beta_{11} \mathrm{SP} 1500+\beta_{12} \text { Instit_Own }+\beta_{13} \mathrm{Ln} \_\mathrm{MVE}+\beta_{14} \mathrm{BTM} \\
& +\beta_{15} \mathrm{ROA}+\beta_{16} \operatorname{Loss}+\beta_{17} \mathrm{Q} \text { ERC }+\beta_{18} \text { Meet_Beat_Hist }+\beta_{19} \mathrm{P} \_ \text {Month_Abn_Ret } \\
& +\beta_{20} \mathrm{P} \_ \text {Month_Ret_Vol }+\beta_{21} \mathrm{P} \_ \text {Month_Turn }+\beta_{22} \text { Ln_Follow }+\beta_{23} \text { Dispersion } \\
& +\beta_{24} \text { After_Hours }+\beta_{25} \text { Other_Press_Cover }+\beta_{\mathrm{i}} \text { Industry_FE }+\beta_{\mathrm{i}} \text { Year_FE } \\
& +\beta_{\mathrm{i}} \text { Month_FE }+\beta_{\mathrm{i}} \text { Day_Of_Week_FE }+\varepsilon \text {. }
\end{aligned}
$$

The dependent variable in the above regression equation, Press_Cover, is an indicator variable equal to one if the guidance received press coverage, and zero otherwise. The independent variables in Equation (1) represent various guidance and firm characteristics that are likely to influence the likelihood that management guidance receives press coverage. The first guidance characteristic is the absolute value of the earnings news contained in the guidance (Abs_Guide_News), where guidance earnings news is defined as the guidance minus the prevailing consensus analyst forecast, scaled by stock price as of two days prior to the guidance.

\footnotetext{
${ }^{12}$ Results for this and all other reported regressions are robust to clustering standard errors by both firm and day, firm and year, industry and day, or industry and year, after removing the corresponding fixed effects from the model (Petersen 2009; Gow et al. 2010).
} 
Solomon and Soltes (2012) document a positive relation between earnings news and press coverage of earnings announcements. For guidance that is bundled with an earnings announcement, I use the measure of conditional guidance news developed in Rogers and Van Buskirk (2012), which specifically accounts for the information provided by the earnings announcement. ${ }^{13}$ In addition to the level of earnings news, the sign of the news is also likely to influence press coverage (Dyck and Zingales 2003; Green et al. 2012). Thus, I include Bad_Guide_News, an indicator variable equal to one if the guidance contains negative earnings news, and zero otherwise.

Other guidance-related factors that may be associated with press coverage include the firm's historical reputation for issuing accurate guidance (Guide_Reputation; Hutton and Stocken 2009), whether the guidance is for quarterly or annual earnings (Annual; Pownall et al. 1993), and the forecasting horizon (Horizon; Baginski and Hassell 1990) and precision (Range; Baginski et al. 1993) of the guidance. Guidance issued with an earnings announcement (Bundled; Rogers and Van Buskirk 2012), and guidance issued on the same day that the firm issues guidance for other periods (Multiple), should generate greater press attention. Guidance press coverage is also likely to be positively associated with coverage of the firm's prior earnings guidance ( $P \_$Guide_Press_Cover).

In terms of firm characteristics, I first consider the firm's recent general coverage in the business press ( $P \_$Month_Press_Cover), as this likely serves as a strong indication of the interest

\footnotetext{
${ }^{13}$ I calculate the consensus analyst forecast as the mean of the most recent forecast issued by each individual analyst during the 90 day period ending three days prior to the guidance date. All results presented throughout the paper are robust to using the median consensus forecast instead of the mean, as well as shortening the pre-guidance window to 60 or 30 days or using the single most recent analyst forecast. Not adjusting bundled guidance earnings news using the conditional expectations model of Rogers and Van Buskirk (2012) does not affect my results. Refer to their paper for a detailed explanation of how the conditional guidance news measure is calculated. See Section 6 for a discussion of additional measures of guidance earnings news. Also, I use analyst forecasts that are not split adjusted (Payne and Thomas 2003). Therefore, I use shares split factors provided in CRSP to ensure that the analyst forecasts and management guidance are based on the same number of shares.
} 
that the press has in the firm. Next, both discussions with reporters and the findings of prior research (e.g., Chen et al. 2004; D’Souza et al. 2010; Li et al. 2011) suggest that firms whose shares are included in major market indexes have increased investor awareness, and are thus of primary interest to the business press. I therefore include an indicator variable equal to one if the firm's stock is included in the S\&P 500, S\&P MidCap 400, or S\&P SmallCap 600 index (SP1500). Further, institutional investors are a key clientele of newswire services (Li et al. 2011), which suggests that guidance issued by firms with greater institutional ownership will be more likely to receive press coverage (Instit_Own). I also include firm size as a more general proxy for the market's demand for information about the firm (Ln_MVE; Bushee et al. 2010).

Based on prior research (e.g., Engelberg 2008; Gaa 2009; Li et al. 2011), other firm characteristics included in my determinants of press coverage model are the book-to-market ratio $(B T M)$, return on assets $(R O A)$, and an indicator variable equal to one for loss firms (Loss). I expect guidance press coverage to be positively associated with the market's response to the firm's recent earnings news $\left(Q \_E R C\right)$, as well as the firm's history of meeting or beating earnings expectations (Meet_Beat_Hist). The firm's recent stock returns $\left(P \_M o n t h \_A b n \_R e t\right)$, return volatility $\left(P \_M o n t h \_R e t \_V o l\right)$, and stock turnover $\left(P \_M o n t h \_T u r n\right)$, as well as analyst following (Ln_Follow) and forecast dispersion (Dispersion), are also likely to be associated with guidance press coverage.

Finally, to proxy for supply-side constraints, I include an indicator for guidance issued after trading hours (After_Hours; Doyle and Magilke 2012), and a count of the number of other firms covered in the press on the day the firm announced the guidance (Other_Press_Cover). ${ }^{14}$

\footnotetext{
${ }^{14}$ Reporters typically specialize in a particular industry. Thus, as an alternative proxy for supply-side constraints, I include Other_Ind_Press_Cover, equal to the number of other firms in the same industry that received press coverage on the guidance date, in Equation (1). In untabulated analysis, the coefficient on this variable is negative and statistically significant $(p$-value $=0.001)$ when the industry fixed effects are omitted from the model.
} 
Because press coverage likely varies across industries (Solomon and Soltes 2012), as well as time, I include industry, year, month, and day of the week fixed effects in this and all subsequent regressions (Hirshleifer et al. 2009).

\subsection{Empirical Results}

I provide descriptive statistics for the variables included in Equation (1) in Panel A of Table 2. Approximately 48 percent of the guidance in my full sample (66,598 observations) received coverage in the business press. With regards to characteristics of the guidance, 49 percent of the management forecasts in my sample contain negative earnings news, 58 percent are annual earnings forecasts, as opposed to quarterly, and 75 percent of the guidance is bundled with an earnings announcement. Additionally, roughly 70 percent of the firms in my sample belong to a major stock index, and the mean firm in my sample reports institutional ownership of 68 percent and return on assets equal to 5 percent.

Panel B of Table 2 presents the results of estimating Equation (1) on my full sample of guidance (coefficients on industry and time fixed effects not reported). The model appears to fit well, with an area under the receiver operator characteristic (ROC) curve of 0.724 , indicating that the model has sufficient discriminatory power (Hosmer and Lemeshow 2000). Further, the p-value of 0.409 on the Hosmer and Lemeshow goodness-of-fit test suggests that I am unable to reject the null hypothesis of good model fit. ${ }^{15}$ To simplify the interpretation of the logistic regression coefficients, the final column of Panel B provides odds ratios for a one standard deviation increase in the continuous independent variables, and a change from zero to one in the indicator variables.

In examining the effects of guidance characteristics on the likelihood of guidance receiving press coverage, I find that guidance containing greater amounts of absolute earnings

\footnotetext{
${ }^{15}$ Multicollinearity does not appear to be a serious concern, as variance inflation factors in this and all other reported regressions are all below three (Belsley et al. 1980).
} 
news (Abs_Guide_News), guidance containing positive earnings news (Bad_Guide_News), quarterly guidance (Annual), range (as opposed to point) guidance (Range), guidance bundled with earnings announcements (Bundled), guidance issued simultaneously with other guidance (Multiple), and guidance issued by firms whose prior guidance received press coverage (P_Guide_Press_Cover), have significantly greater probabilities of receiving coverage in the business press relative to other guidance (all p-values $<0.001$ ). As examples of the economic magnitude of these effects: a one standard deviation increase in Abs_Guide_News is associated with a $9.5 \%$ increase in the odds of guidance receiving press coverage; annual guidance are $12.6 \%$ less likely to receive coverage than quarterly guidance (Annual); and bundled guidance (Bundled) are 51.4\% more likely to receive coverage than unbundled guidance.

Several firm characteristics are also systematically associated with the likelihood that guidance will receive press coverage. Specifically, the firm's overall coverage in the business press during the prior month (P_Month_Press_Cover), inclusion in a major stock index (SP1500), institutional ownership (Instit_Own), the market's response to the firm's recent earnings news $\left(Q_{-} E R C\right)$, and the firm's recent history of meeting or beating earnings expectations (Meet_Beat_Hist), are all positively associated with the probability of guidance receiving coverage in the business press. Meanwhile, firm size $\left(L n \_M V E\right)$, stock return volatility during the prior month $\left(P \_M o n t h \_R e t \_V o l\right)$ and the incidence of press coverage of other firms (Other_Press_Cover) are negatively associated with guidance press coverage. ${ }^{16}$ With regard to economic magnitude, a one standard deviation increase in $P \_$Month_Cover (Instit_Own) is

\footnotetext{
${ }^{16}$ The negative coefficient on $L n \_M V E$ is inconsistent with expectations. It should be noted that the univariate correlation between Press_Cover and $L n \_M V E$ is positive and significant ( $\mathrm{p}$-value $=0.001$ ). However, the correlations between $L n \_M V E$ and P_Month_Press_Cover, SP1500, and Ln_Follow are all positive, significant, and greater than 30 percent. Including these variables together in the determinants model appears to induce the negative association documented between Ln_MVE and Press_Cover.
} 
associated with a $26.2(5.2) \%$ increase in the odds of guidance receiving press coverage, while being listed on a major stock index (SP1500) increases the probability of coverage by $20.9 \%$.

Overall, a comparison of management earnings guidance that received press coverage to guidance that did not receive coverage reveals a number of systematic differences between the two sets of observations. Because many of these firm and guidance characteristics may also affect the observed capital market responses to guidance, it is important to appropriately control for these factors in my analyses of the market consequences of guidance press coverage. This motivates the use of a matched sample research design in my subsequent tests, as discussed in the following section. 


\section{MARKET REACTION TO GUIDANCE PRESS COVERAGE}

\subsection{Research Method}

My primary hypothesis posits that market participants react more strongly to management earnings guidance that receives coverage in the business press. To empirically test this hypothesis, I estimate the following pooled cross-sectional OLS regressions, again with standard errors clustered by firm: ${ }^{17}$

$$
\begin{aligned}
& \operatorname{Abn} \_\operatorname{Return}(0,1)=\alpha+\beta_{1} \text { Guide_News }+\beta_{2} \text { Press_Cover } \\
& +\beta_{3} \text { Guide_News } * \text { Press_Cover }+\beta_{4} \text { Fraction }+\beta_{5} \text { Guide_Reputation }+\beta_{6} \text { Horizon } \\
& +\beta_{7} \text { Range }+\beta_{8} \mathrm{P} \_ \text {Month_Press_Cover }+\beta_{9} \text { Instit_Own }+\beta_{9} \mathrm{Ln} \_\mathrm{MVE}+\beta_{10} \mathrm{BTM} \\
& +\beta_{12} \text { Ln_Follow }+\beta_{13} \text { Dispersion }+\beta_{\mathrm{i}} \text { Industry_FE }+\beta_{\mathrm{i}} \text { Year_FE }+\beta_{\mathrm{i}} \text { Month_FE } \\
& +\beta_{\mathrm{i}} \text { Day_Of_Week_FE }+\varepsilon \text {. } \\
& \text { Fraction }=\alpha+\beta_{1} \text { Abs_Guide_News }+\beta_{2} \text { Press_Cover } \\
& +\beta_{3} \text { Abs_Guide_News*Press_Cover }+\beta_{4} \mathrm{Abs} \_ \text {Abn_Return }(0,1)+\beta_{5} \text { Guide_Reputation } \\
& +\beta_{6} \text { Horizon }+\beta_{7} \text { Range }+\beta_{8} \mathrm{P} \_ \text {Month_Press_Cover }+\beta_{9} \text { Instit_Own }+\beta_{9} \text { Ln_MVE } \\
& +\beta_{10} \text { BTM }+\beta_{12} \text { Ln_Follow }+\beta_{13} \text { Dispersion }+\beta_{\mathrm{i}} \text { Industry_FE }+\beta_{\mathrm{i}} \text { Year_FE } \\
& +\beta_{\mathrm{i}} \text { Month_FE }+\beta_{\mathrm{i}} \text { Day_Of_Week_FE }+\varepsilon \text {. }
\end{aligned}
$$

Equations (2) and (3) estimate the effects of press coverage on the investor and analyst reactions to guidance earnings news, respectively. In Equation (2), the dependent variable $\left(A b n \_\right.$Return $\left.(0,1)\right)$ is defined as the raw buy-and-hold stock return over the two day period beginning the day the guidance was announced less the buy-and-hold return to one of the benchmark portfolios formed based on size, book-to-market, and momentum $(5 * 5 * 5)$, similar to

\footnotetext{
${ }^{17}$ I winsorize all continuous variables except for stock returns at the first and $99^{\text {th }}$ percentiles to alleviate the effects of outliers on the analysis. To provide confirmation that my results are not unduly affected by outliers, I estimate this and subsequent models using robust regressions based on MM-estimation as well as median regressions and find consistent results (Leone et al. 2012).
} 
Hirshleifer et al. (2009) and Drake et al. (2012). ${ }^{18}$ In Equation (3), the dependent variable (Fraction) is defined as the number of analysts who revise their earnings forecasts for the firm during the same two day period, scaled by the total number of analysts following the firm's stock, similar to Cotter et al. (2006) and Kross and Suk (2012). ${ }^{19}$

The first two independent variables in Equations (2) and (3) are the earnings news contained in the guidance (Guide_News or Abs_Guide_News) and the press coverage indicator variable (Press_Cover), as defined previously. The coefficient on the interaction term of these two variables $\left(\beta_{3}\right)$ in Equation (2) indicates the extent to which business press coverage affects the stock price reaction to the earnings news provided by the guidance, while the interaction coefficient in Equation (3) provides evidence on the influence of guidance press coverage on the fraction of analysts who immediately revise their forecasts in response to the guidance. ${ }^{20} \mathrm{~A}$ positive and significant $\beta_{3}$ in these regressions thus provides support for $\mathrm{H}_{1}$. Because the investor and analyst reactions likely affect each other, I control for the analyst reaction in the investor reaction regression, and vice versa. I also include several other variables to control for factors that prior research has shown to affect the market reaction to guidance (e.g., Hutton and Stocken 2009; Ball et al. 2012; Yang 2012). ${ }^{21}$

\footnotetext{
${ }^{18}$ The use of market-adjusted returns, size-adjusted returns, a three day (-1 to 1$)$ return window, or a five day (-2 to 2) return window does not affect my inferences. Results are also robust to standardizing Abn_Return $(0,1)$ by the standard deviation of returns over the prior month (Ball et al. 2012). I assign firms to size, book-to-market, and momentum portfolios in June of each year. When a firm cannot be assigned to a particular portfolio in a year, I use size-adjusted returns instead. Eliminating these firms from the sample does not impact my results.

${ }^{19}$ I find similar results when I measure Fraction over a five day window (Kross and Suk 2012).

${ }^{20}$ The main effect of Press_Cover captures the effect of press coverage that relates to any information conveyed in the announcement that is not reflected in the guidance news. For example, Clement et al. (2003) find that confirming guidance (i.e., Guide_News $=0$ ) elicits a positive market reaction, which they attribute to a reduction in uncertainty.

${ }^{21}$ Results are robust to including interaction terms of Guide_News or Abs_Guide_News with all of the control variables, although this introduces substantial multicollinearity into the model.
} 


\subsection{Matched Samples}

As noted in prior studies, press coverage is not an exogenous variable in capital markets research (e.g., Bushee et al. 2010; Soltes 2010). In my setting, reporters may decide to cover management guidance based on firm or guidance characteristics that also influence the market reaction to the guidance. Failure to control for this selection bias when estimating Equations (2) and (3) could lead to biased inferences. Conceptually, I am interested in the difference between the observed outcome for guidance that received press coverage and the counterfactual outcome (i.e., the market reaction if the guidance had not received press coverage). Because my study, like most empirical accounting research, is observational in nature, the counterfactual outcome is unobservable. Accordingly, I examine the market consequences of guidance press coverage by comparing guidance that received press coverage to two matched samples of guidance that did not receive press coverage. This research method allows me to more clearly attribute the observed market consequences to the press coverage itself, rather than to firm or guidance characteristics associated with press coverage.

I first use propensity-score matching (PSM) to identify a sample of guidance that did not receive press coverage, but is otherwise similar across all observable dimensions to the covered guidance (Armstrong et al. 2010). For my second matched sample of guidance, I match each covered guidance observation with a non-covered guidance observation issued by the same firm within one year of the covered guidance (Christensen et al. 2012). I present results throughout the paper using both samples of matched guidance. I also base my discussions throughout the remainder of the paper on results obtained from using the stand-alone guidance sample because stand-alone guidance is more discretionary in nature than bundled guidance (Kim et al. 2012), and the focus of this paper is on voluntary (i.e., discretionary) disclosures. In addition, there are significant difficulties associated with disentangling the market consequences of bundled 
guidance from the effects of the related earnings announcements (Rogers and Van Buskirk 2012). However, my results are robust to using the full sample of guidance, after adjusting bundled guidance news using the conditional expectations model developed in Rogers and Van Buskirk (2012), and these results are presented alongside the results using the stand-alone guidance sample for the sake of generalizability.

In order to identify the PSM sample of guidance, I estimate Equation (1) on my sample of 9,286 stand-alone guidance observations. I then match (without replacement) each guidance observation that received press coverage with a non-covered guidance observation from another firm in the same year that has the closest propensity-score, or predicted value, from Equation (1), within a maximum distance of 1 percent. ${ }^{22}$ This process results in a final sample of 2,499 covered stand-alone guidance observations and 2,499 matched (non-covered) observations. To ensure that the covered and matched guidance samples are similar across all observable dimensions except for the treatment effect (i.e., press coverage), I examine covariate balance in Table 3. As shown in the final two columns of Table 3, there are no significant differences in the means of the independent variables in Equation (1) upon completion of the matching process, and only two of the nineteen variables exhibit a significant difference in medians. ${ }^{23}$ These results indicate that covariate balance is achieved along relevant variable dimensions (Tucker 2011).

\footnotetext{
${ }^{22}$ I require the treatment and control guidance to come from different firms in order to ensure unique control samples between the PSM and within-firm matched samples. I use the nearest neighbor matching method of PSM with common support. My inferences do not change if I increase the maximum distance in propensity scores to 5, 10, or 15 percent, or match with replacement. Refer to Li and Prabhala (2007), Tucker (2011), and Lennox et al. (2012) for more detailed discussions on the implementation of PSM, as well as its advantages and disadvantages.

${ }^{23}$ In untabulated analysis, the results of non-parametric Kolmogorov-Smirnov homogenous distributions tests indicate that 15 of the 19 variables in Equation (1) have statistically equivalent distributions. The four variables that do not are Abs_Guide_News, Horizon, P_Month_Press_Cover, and Dispersion. To be conservative, these variables are included as control variables in my subsequent analyses. Additionally, including all of the variables from the first stage model as control variables in my subsequent tests does not affect my results.
} 
In addition to PSM, I employ a second matching procedure in which a firm is used as its own control. For each covered guidance observation, I identify a non-covered guidance observation issued by the same firm within one year of the covered guidance. I also require each pair of covered and non-covered guidance to be comparable with respect to forecasting quarterly or annual earnings, and I only allow a non-covered guidance observation to be used once (i.e., matching without replacement). If more than one possible match is found, I select the matched pair with the closest levels of earnings news. This results in a sample of 1,046 covered standalone guidance observations and 1,046 matched observations. The advantage of this design is that it removes across-firm heterogeneity in observable or unobservable characteristics of the firms that may influence both press coverage and the market consequences of guidance (e.g., firm visibility). The use of both across-firms (PSM) and within-firm matched samples of guidance allows me to more clearly attribute the observed market consequences to press coverage itself, and I present results throughout the paper using both samples of matched guidance. In addition, all results are robust to using the full (non-matched) sample of guidance (untabulated).

\subsection{Empirical Results}

Table 4 presents descriptive statistics for the variables in Equations (2) and (3) for the full, PSM, and within-firm matched samples of stand-alone guidance. Although many of the control variables exhibit significantly different means between the samples of covered and noncovered guidance before matching, these differences are generally eliminated after matching. Further, unsigned measures of the investor and analyst reactions to guidance (Abs_Abn_Return $(0,1)$ and Fraction) remain significantly different across the two groups of guidance after matching. Specifically, average absolute price reactions are more than a percentage point greater for covered guidance in both matched samples, and the fraction of 
analysts who revise their forecasts immediately after the guidance increases from $26.16 \%$ to $42.07 \%$ when the guidance receives press coverage in the PSM sample (an increase of $60.82 \%$ ). These results provide preliminary evidence that press coverage is associated with an increased market reaction to guidance, even after controlling for factors that may influence press coverage through matching.

Panel A of Table 5 presents the results of estimating Equation (2), my primary investor reaction model. Columns 1-4 contain results using the PSM sample of stand-alone guidance, the PSM sample of all guidance, the within-firm matched sample of stand-alone guidance, and the within-firm matched sample of all guidance, respectively. As expected, the coefficient on Guide_News is positive and significant in all four samples, indicating that investors respond positively to the earnings news contained in management guidance. More importantly, the coefficient on the interaction term of guidance news and press coverage (Guide_News*Press_Cover) is positive and significant in each regression, consistent with $\mathrm{H}_{1}$. With respect to economic magnitude, the results in the first column indicate that a one standard deviation increase in Guide_News for guidance without press coverage is associated with an average two day abnormal stock return of $2.14 \%(2.381 * 0.009)$, holding all else constant. However, a one standard deviation increase in Guide_News for guidance with press coverage is associated with an average return of $4.07 \%((2.381+2.144) * 0.009)$. In other words, guidance press coverage results in an average $90 \%$ increase in the investor reaction to the information contained in the guidance. ${ }^{24}$

\footnotetext{
${ }^{24}$ As an alternative way of thinking about the economic magnitude of this result, consider the following example: Firm A has a consensus analyst forecast of $\$ 2.00$ prior to announcing guidance of $\$ 2.10$, and firm A's stock price is $\$ 20.00$. Firm A's value of Guide_News would be $0.005((\$ 2.10-\$ 2.00) / \$ 20.00)$. If firm A's guidance did not receive press coverage, we would expect the price reaction to firm A's guidance news to be $1.19 \%(2.381 * 0.005)$, ceteris paribus. However, if the guidance did receive press coverage, we would expect the price reaction to the guidance news to be $2.26 \%((2.381+2.144) * 0.005)$.
} 
Panel B of Table 5 presents the estimation results for Equation (3), which examines the analyst reaction to press coverage of guidance. The coefficient on Abs_Guide_News*Press_Cover is positive and significant at the one percent level in all four regressions. These results suggest that press coverage significantly increases the percentage of analysts who revise their earnings forecasts immediately following the announcement of guidance. Taken together, the results presented in Table 5 are consistent with $\mathrm{H}_{1}$ and provide strong evidence that the business press plays an important role in disseminating management earnings guidance information to market participants. ${ }^{25}$

\footnotetext{
${ }^{25}$ In untabulated analyses, I also examine the effect of press coverage on other measures of the investor and analyst reactions to guidance. I find that press coverage is positively associated with the abnormal trading volume reaction to guidance (Ball et al. 2012), as well as the amount of guidance news incorporated by analysts into their subsequent forecast revisions (Merkley et al. 2012), and the average speed with which analysts revise their forecasts following the guidance announcement (Kross and Suk 2012). In addition, there is a greater increase (decrease) in analyst forecast accuracy (dispersion) following guidance announcements when the guidance receives press coverage.
} 


\section{ADDITIONAL ANALYSES}

The results thus far indicate that there is systematic variation in the extent to which management earnings guidance news is disseminated through the business press, and that this variation has a significant effect on the market reaction to guidance. In this section, I extend these results by first examining the effect of guidance press coverage on subsequent stock price drift and the distribution of long-window returns. I also explore differences in my results across various sample partitions, as well as the sensitivity of my findings to alternative econometric specifications and empirical measures.

\subsection{Price Drift}

In my primary analyses I document a significant increase in the initial price reaction to guidance news when the guidance receives coverage in the business press. A natural extension of this result is to examine stock price drift subsequent to the announcement of guidance. Recent research provides evidence of an association between investor attention and post-earnings announcement drift (PEAD). For example, Hirshleifer et al. (2009) find that PEAD is greater when more firms announce earnings on the same day, and Dellavigna and Pollet (2009) report that PEAD is larger for Friday earnings announcements. If press coverage results in a more complete initial reaction to guidance news, then we may observe a reduced delayed reaction (i.e., less price drift) when guidance receives press coverage.

To test this assertion, I regress future abnormal returns measured over two windows (2,10 and 2,30, where day 0 is the guidance date) on the earnings news contained in the guidance, the press coverage indicator variable, and their interaction term. Because price drift is strongest amongst firms with relatively extreme earnings news (Bernard and Thomas 1989, 1990), I follow prior research in sorting Guide_News into quintiles by year, and including only those guidance observations in the top and bottom quintiles in the sample in order to obtain a 
more powerful test (e.g., Hirshleifer et al. 2008, 2009; Dellavigna and Pollet 2009; Boulland et al. 2012). I then include an indicator variable equal to one for the highest quintile of Guide_News (Top_Q_Guide_News) in the regressions. I also include the same set of control variables as Equation (2), as well as the initial price reaction $\left(A b n \_\right.$Return $\left.(0,1)\right)$.

The results of this analysis are presented in Table 6 . In order to ensure that the effect captured here is independent of PEAD, I only use stand-alone (i.e., non-bundled) guidance observations in these regressions. The first and second columns contain results using the PSM matched sample with abnormal returns measured over a $(2,10)$ and $(2,30)$ day window, respectively. The third and fourth columns contain the same results using the within-firm matched sample. In three of the four regressions, I find a positive and significant coefficient on $T o p \_Q \_$Guide_News, providing evidence of price drift following the announcement of standalone guidance. In each of the three regressions, I also find a negative and significant coefficient on the interaction term Top_Q_Guide_News*Press_Cover (p-values $<0.05$ ), suggestive of a reduction in drift when guidance receives press coverage. However, I also find significantly positive coefficients on the main effect of press coverage (Press_Cover), and as shown in the last row of the table, F-tests of Top_Q_Guide_News*Press_Cover + Press_Cover $=0$ are all statistically insignificant. These results suggest that the total effect of guidance press coverage on subsequent price drift is not statistically different from zero.

\subsection{Long-Window Returns Portfolios}

The results in Table 5 indicate that business press coverage increases the initial $(0,1)$ price reaction to guidance news, while Table 6 examines the effect of press coverage on price drift subsequent to guidance announcements over the $(2,10)$ and $(2,30)$ windows. In this section, I combine these time periods and compare the timing of return realizations for covered and noncovered guidance. Specifically, I first sort guidance observations into quintiles by year based on 
the firms' abnormal returns over days $(0,10)$ or $(0,30)$. I then examine the distribution of mean returns within each return quintile across days $(0,1)$ and $(2,10)$ or $(2,30)$ for covered and noncovered guidance separately, and compare differences between the two types of guidance. ${ }^{26}$ This methodology not only matches guidance on ex ante characteristics (through the use of PSM and within-firm matched samples), but guidance is also matched (sorted) on ex post returns. To the extent that returns over these longer windows capture the total information content of the guidance, this sorting process ensures that covered and non-covered guidance observations within the same quintiles provided the market with similar amounts of information. While the long-term information content of the guidance within each total return quintile is equivalent, I expect the returns of covered guidance to be concentrated in days $(0,1)$, and the returns for noncovered guidance to be concentrated in days $(2,10$ or 2,30$)$.

The results of this analysis are presented in Table 7. I focus my discussion on the results in the first four rows based on the PSM sample of stand-alone guidance, although I obtain similar results using the within-firm matched sample of guidance, as presented in the final four rows. I find that in the lowest quintile of long-window returns, covered guidance has a more negative initial $(0,1)$ reaction than non-covered guidance. Similarly, in the highest quintile of total returns, covered guidance has a more positive initial reaction than non-covered guidance. However, these relations are reversed in the delayed price reactions $(2,10$ or 2,30$)$, where noncovered guidance has a more negative delayed reaction in the lowest quintile of total returns, and a more positive delayed reaction in the highest quintile of total returns. These differences are all significant at the five percent level. The final column of Table 7 provides p-values for tests of the equality of Guide_News across covered and non-covered guidance within each total return quintile. The lack of significant differences here indicates that these results are not being driven

\footnotetext{
${ }^{26}$ I find similar results using median returns (untabulated).
} 
by differences in the quantitative information contained in the guidance. Taken together, the results in Table 5-7 provide strong evidence that press coverage significantly effects the market consequences of management earnings guidance, and these relations hold even when controlling for ex ante firm and guidance characteristics (through matching), as well as long-window returns (through sorting).

\subsection{Comparison of Stand-Alone and Bundled Guidance}

In this section, I examine the moderating effect of guidance bundling with earnings announcements on the investor reaction to guidance press coverage. Due to the publicity associated with earnings announcements, I expect bundled guidance to be more expected by the market and less dependent on dissemination through the business press relative to stand-alone guidance (Doyle and Magilke 2012). To test this assertion, I compare the effect of press coverage on the investor reaction to guidance news for my sample of stand-alone guidance to the same effect for my sample of bundled guidance. The results of re-estimating Equation (2) for these two samples are presented in Table 8 . I find that press coverage has a larger effect on the investor reaction to stand-alone guidance compared to bundled guidance. This difference appears to be substantial, as the coefficient on Guide_News*Press_Cover in the stand-alone guidance sample (2.212) is more than four times larger than the same coefficient in the bundled guidance sample (0.542). The 1.670 difference between these coefficients is significant at the one percent level.

\subsection{Heckman Selection Model}

The use of both across-firms (PSM) and within-firm matched samples of guidance in my main tests allows me to more clearly attribute the observed market consequences to press coverage itself, rather than to firm or guidance characteristics associated with press coverage. As an alternative, non-matching based approach to addressing potential selection bias, I use a 
Heckman two-stage selection model (Heckman 1979). To implement this approach, I use my determinants of guidance press coverage model (Equation 1) as the first stage probit model. The Heckman selection model requires the identification of an exogenous independent variable in the first stage model that can be validly excluded from the second stage model (Lennox et al. 2012). For my exclusion restriction, I select $P \_$Guide_Press_Cover, as Table 2 documents that press coverage of the firm's prior guidance is significantly associated with current guidance press coverage, and this variable should not be associated with the market reaction to the current guidance (including it in the regressions confirms this lack of association).

The results of the second stage regressions (Equations 2 and 3) including the inverse Mills ratio (Inv_Mills) are shown in Table 9. For expositional purposes I only report the coefficients and p-values on the variables of interest in each test. Although the coefficients on Inv_Mills and Guide_News*Inv_Mills or Abs_Guide_News*Inv_Mills are significant in several of the regressions, I continue to find results consistent with those presented in Table 5 after controlling for selection due to unobservable factors. The positive and significant coefficients on Guide_News*Inv_Mills and Abs_Guide_News*Inv_Mills suggest that unobservable factors related to guidance press coverage are associated with stronger market reactions to guidance news. $^{27}$

\subsection{Simultaneity Bias}

Table 5 documents that business press coverage significantly increases the stock price reaction to guidance. A potential alternative explanation for this finding is that guidance press coverage is endogenously determined with the price reaction. In other words, it is possible that the press decides to cover an event because it elicits a strong price reaction immediately upon its

${ }^{27}$ The price drift results presented in Table 6 are also robust to the use of a Heckman selection model (untabulated). As discussed in Lennox et al. (2012), multicollinearity is a concern when using the Heckman model. However, the variance inflation factors in all of the regressions reported in Table 9 are below 3 . 
release. ${ }^{28}$ This is unlikely to be the case in my setting, as newswire reporters typically issue articles within a matter of seconds or minutes after receiving the information (Soltes 2010; Rogers et al. 2013), and therefore must make their coverage decisions independent of any subsequent market-based information. ${ }^{29}$

Nevertheless, to address any potential endogeneity concerns related to simultaneity bias, I re-estimate my investor reaction model (Equation 2) on the sub-sample of management guidance that was issued after the market closed (from 4:01pm through 11:59pm). I also calculate the price reactions for day $\mathrm{t}$ (the day the guidance was issued) and day $\mathrm{t}+1$ separately, instead of the two-day windows used in my primary analyses. Because these management forecasts were issued after market hours, the investor reaction should occur on the following day. Therefore, because press coverage is measured on day $t$, the investor reaction (on day $t+1$ ) cannot influence the press coverage decision, but press coverage can influence the subsequent investor reaction. As expected, using only those guidance observations that were issued after the market closed, I find no price reaction to guidance press coverage on day t. However, when examining the investor reaction on day $\mathrm{t}+1$, I find results consistent with those of my primary analyses. These results suggest that simultaneity bias is not a primary explanation for my findings. ${ }^{30}$

\footnotetext{
${ }^{28}$ Bushee et al. $(2010,12)$ document a positive relation between firms' general press coverage around earnings announcements and the price reaction to the announcements. They note that while this may indicate that the press views large price reactions as newsworthy, it is also consistent with the notion that the press coverage is influencing the price reactions. Because their focus is on information asymmetry, they do not attempt to distinguish between these two explanations.

${ }^{29}$ My conversations with newswire reporters confirm that their goal is to release their articles in the shortest amount of time possible, and accordingly, they do not wait to base their coverage decisions on the market reaction. This is consistent with Rogers et al. (2013), who find that the majority of DJ Newswire articles related to insider trading events are published in less than two minutes following the EDGAR filing.

${ }^{30}$ Of the 4,998 observations in the PSM sample of stand-alone guidance, 1,625 were issued after the market closed. A further 2,357 were issued before the market opened (from 12:01am to 9:29am), and more than $90 \%$ of these before hours guidance observations that received press coverage received their first
} 


\subsection{Alternative Empirical Measures}

Finally, I examine the robustness of my results to the use of alternative measures of guidance press coverage and guidance earnings news. As an alternative measure of guidance press coverage, I use a database provided by RavenPack consisting of all articles published in the following sources: Associated Press, Wall Street Horizon, Midnight Trader, RTT News, and Canadian Press. Because RavenPack does not provide articles from these sources prior to 2007, the sample period for this analysis is 2007 to 2010 . In untabulated analysis, I find results consistent with those of my primary analyses measuring guidance press coverage using only these alternative sources. ${ }^{31}$

As my first alternative measure of guidance earnings news, I sort Guide_News into quintiles by year, and use the quintile rankings in my regressions. Quintile rankings do not require a monotonic association between guidance earnings news and the dependent variables such as stock returns (Armstrong et al. 2010). Quintiles also have the advantage of alleviating the effects of outliers and skewness in the distribution of guidance earnings news. Replacing Guide_News with its quintile rank, I find results qualitatively similar to those presented in Table 5 (untabulated). I also find consistent results using a non-scaled measure of Guide_News (Cheong and Thomas 2011). Lastly, because prior research finds that there is an asymmetric price reaction to good and bad news guidance (Skinner 1994; Kothari et al. 2009a), I estimate Equation (2) separately for good and bad news guidance. In untabulated analysis, I find strong evidence of a price reaction to press coverage of both good and bad news guidance. I also find

article before the market opened. Thus, the investor reaction is not likely to have influenced the coverage decisions of these observations as well.

${ }^{31}$ The magnitude of the effect of guidance press coverage is generally larger in this analysis relative to those of my primary analyses using DJ Newswires. This is not surprising given that only $7 \%$ of my sample of stand-alone guidance received coverage in one of these sources, compared to over $30 \%$ in DJ. Because these sources are less likely to cover guidance compared to DJ, when they do cover guidance, it is likely an indication that the guidance received widespread dissemination elsewhere as well. 
that the difference across the coefficients on Guide_News*Press_Cover in the two sample partitions is not statistically significant ( $p$-value $=0.447$ ). 


\section{CONCLUSIONS}

In this study, I provide evidence on the role of the business press in disseminating management earnings guidance news to capital market participants by examining the determinants and consequences of guidance press coverage. Based on the findings of recent empirical and theoretical studies, I hypothesize that the capital market consequences of management guidance are dependent on the effective communication of guidance news to the market, and that the business press, in its role as an information intermediary, facilitates this process by disseminating the information contained in guidance to market participants. I find that both investors and analysts react significantly more strongly to guidance that receives coverage in the business press. This study is the first to provide evidence that there is systematic variation in the extent to which guidance information is disseminated, and that this variation has a significant effect on the market consequences of guidance. This study is also the first to provide evidence that the forecasting decisions of financial analysts are affected by the press' coverage of the firms they follow.

Managers whose guidance receives press coverage can have their private information more fully impounded into stock prices and thus reduce information asymmetry (Ajinkya and Gift 1984; Hutton and Stocken 2009). Prior research has generally taken the market reaction to management guidance to be a function of the earnings news provided by the guidance and the credibility of the guidance (Jennings 1987). However, the results of this study indicate that dissemination in the business press is an additional determinant of the market response to guidance, and an economically significant one. Developing a greater understanding of the factors that explain the variation in market reactions to management earnings guidance should be of interest to researchers, investors, analysts, regulators, and managers themselves. 
One potential limitation of this study is that the sample of articles is restricted to those articles contained within the DJ Newswires. Thus, it is possible that management earnings guidance identified as not receiving press coverage could have received coverage in some other source. However, $D J$ has been utilized in numerous prior studies in accounting and finance (e.g., Barber and Odean 2008; Tetlock 2010, 2011; Engelberg et al. 2012). ${ }^{32}$ As noted in prior research, identifying the firms discussed in business press articles, classifying articles as firm- or press-initiated, and identifying the relevance of an article to a specific firm are difficult and error-prone tasks using traditional sources of business press data such as Factiva or Lexis-Nexis (e.g., Engelberg 2008; Soltes 2010). A significant advantage of the business press data used in this study, as provided by RavenPack, is that it enables me to accurately identify the firm discussed in the article, the relevance of the article to the firm, and most importantly for the sake of this study, the event discussed in the article, which would be difficult using an alternative data source. Accordingly, the sample used in this study is likely to be an effective proxy for business press coverage of management guidance. To the extent that this proxy contains measurement error, that measurement error should bias against my ability to find significant results.

\footnotetext{
${ }^{32}$ As Chan $(2003,230)$ notes, "by far the sources with the most complete coverage across time and stocks are the DJ newswires. This source does not suffer from gaps in coverage, and it is the best approximation of public news for traders." Chan also reports that his results are unchanged when he restricts his sample to the DJ news archives to the exclusion of the other eight business press sources in his sample (footnote $3)$. Additionally, Tetlock $(2011,5)$ states that, "the DJ Newswires represent the most widely circulated financial news in the United States, and the DJ Newswire arguably has the most comprehensive coverage."
} 


\section{REFERENCES}

Ajinkya, B., and M. Gift. 1984. Corporate managers' earnings forecasts and symmetrical adjustments of market expectations. Journal of Accounting Research 22: 425-444.

Armstrong, C., A. Jagolinzer, and D. Larcker. 2010. Chief executive officer equity incentives and accounting irregularities. Journal of Accounting Research 48: 225-272.

Baginski, S., and J. Hassell. 1990. The market interpretation of management earnings forecasts as a predictor of subsequent financial analyst forecast revisions. The Accounting Review 65: $175-190$.

Baginski, S., E. Conrad, and J. Hassell. 1993. The effects of management forecast precision on equity pricing and on the assessment of earnings uncertainty. The Accounting Review 68: 913-927.

Ball, R., S. Jayaraman, and L. Shivakumar. 2012. Audited financial reporting and voluntary disclosure as complements: A test of the confirmation hypothesis. Journal of Accounting and Economics 53: 136-166.

Bamber, L., and Y. Cheon. 1998. Discretionary management earnings forecast disclosures: Antecedents and outcomes associated with forecast venue and forecast specificity choices. Journal of Accounting Research 36: 167-190.

Barber, B., and T. Odean. 2008. All that glitters: The effect of attention and news on the buying behavior of individual and institutional investors. Review of Financial Studies 21: 785818.

Belsley, D., E. Kuh, and R. Welsch. 1980. Regression diagnostics. John Wiley, New York.

Bernard, V., and J. Thomas. 1989. Post-earnings-announcement drift: Delayed price response or risk premium? Journal of Accounting Research 27: 1-48.

Bernard, V., and J. Thomas. 1990. Evidence that stock prices do not fully reflect the implications of current earnings for future earnings. Journal of Accounting and Economics 13: 305340.

Beyer, A., D. Cohen, T. Lys, and B. Walther. 2010. The financial reporting environment: Review of the recent literature. Journal of Accounting and Economics 50: 296-343.

Blankespoor, E., G. Miller, and H. White. 2013. The role of dissemination in market liquidity: Evidence from firms' use of Twitter. Working paper, Stanford University and University of Michigan.

Bloomfield, R. 2002. The "incomplete revelation hypothesis" and financial reporting. Accounting Horizons 16: 233-243. 
Boulland, R., F. Degeorge, and E. Ginglinger. 2012. Targeted communication and investor attention. Working paper, University Paris-Dauphine.

Bradshaw, M., G. Miller, and G. Serafeim. 2009. Accounting method heterogeneity and analysts' forecasts. Working paper, University of Chicago, University of Michigan, and Harvard University.

Bushee, B., J. Core, W. Guay, and S. Hamm. 2010. The role of the business press as an information intermediary. Journal of Accounting Research 48: 1-19.

Chan, W. 2003. Stock price reaction to news and no-news: Drift and reversal after headlines. Journal of Financial Economics 70: 223-260.

Chen, H., G. Noronha, and V. Singal. 2004. The price response to S\&P 500 index additions and deletions: Evidence of asymmetry and a new explanation. The Journal of Finance 59: 1901-1929.

Cheong, F., and J. Thomas. 2011. Managerial smoothing of analysts' EPS forecast errors: Explanations and implications. Working paper, Rutgers University and Yale University.

Christensen, T., M. Drake, and J. Thornock. 2012. Optimistic reporting and pessimistic investing: Do pro forma earnings disclosures attract short sellers? Forthcoming in Contemporary Accounting Research.

Chuk, E., D. Matsumoto, and G. Miller. 2013. Assessing methods of identifying management forecasts: CIG vs. researcher collected. Journal of Accounting and Economics 55: 23-42.

Clement, M., R. Frankel, and J. Miller. 2003. Confirming management earnings forecasts, earnings uncertainty, and stock returns. Journal of Accounting Research 41: 653-679.

Coller, M., and T. Yohn. 1997. Management forecasts and information asymmetry: An Examination of Bid-Ask Spreads. The Accounting Review 35: 181-191.

Cotter, J., I. Tuna, and P. Wysocki. 2006. Expectations management and beatable targets: How do analysts react to public earnings guidance? Contemporary Accounting Research 23: 593-624.

Dellavigna, S., and J. Pollet. 2009. Investor inattention and Friday earnings announcements. Journal of Finance 64: 709-749.

Diamond, D. 1985. Optimal release of information by firms. Journal of Finance 40: 1071-1094.

Doyle, J. and M. Magilke. 2012. The strategic timing of management forecasts. Working paper, Claremont McKenna College and Utah State University.

Drake, M., D. Roulstone, and J. Thornock. 2012. Investor information demand: evidence from Google searches around earnings announcements. Journal of Accounting Research 50: 1001-1040. 
D’Souza, J., K. Ramesh, M. Shen. 2010. The interdependence between institutional ownership and information dissemination by data aggregators. The Accounting Review 85: 159-193.

Dyck, A., and L. Zingales. 2003. The bubble and the media. Oxford University Press, New York.

Engelberg, J. 2008. Costly information processing: Evidence from earnings announcements. Working paper, University of North Carolina.

Engelberg, J., and C. Parsons. 2011. The causal impact of media in financial markets. Journal of Finance 66: 67-97.

Engelberg, J., A. Reed, and M. Ringgenberg. 2012. How are shorts informed? Short Sellers, news, and information processing. Journal of Financial Economics 105: 260-278.

Fang, L., and J. Peress. 2009. Media coverage and the cross-section of stock returns. Journal of Finance 64: 2023-2052.

Feng, M., and A. Koch. 2010. Once bitten, twice shy: The relation between outcomes of earnings guidance and management guidance strategy. The Accounting Review 85: 1951-1984.

Feng, M., and S. McVay. 2010. Analysts' Incentives to overweight management guidance when revising their short-term earnings forecasts. The Accounting Review 85: 1617-1646.

Gaa, C. 2009. Asymmetric attention to good and bad news and the neglected firm effect in stock returns. Working paper, University of Oregon.

Gow, I., G. Ormazabal, and D. Taylor. 2010. Correcting for cross-sectional and time-series dependence in accounting research. The Accounting Review 85: 483-512.

Graham, J., C. Harvey, and S. Rajgopal. 2005. The economic implications of corporate financial reporting. Journal of Accounting and Economics 40: 3-73.

Green, J., J. Hand, and M. Penn. 2012. The bad news dissemination bias in the business press. Working paper, The Pennsylvania State University, University of North Carolina, and Florida State University.

Grossman, S., and J. Stiglitz. 1980. On the impossibility of informationally efficient markets. The American Economic Review 70: 393-408.

Heckman, J. 1979. Sample selection bias as a specification error. Econometrica 47: 153-161.

Hilary, G., and C. Hsu. 2011. Endogenous overconfidence in managerial forecasts. Journal of Accounting and Economics 51: 300-313.

Hirshleifer, D., S. Lim, and S. Teoh. 2009. Driven to distraction: Extraneous Events and underreaction to earnings news. Journal of Finance 5: 2289-2325.

Hirshleifer, D., and S. Teoh. 2003. Limited attention, information disclosure, and financial reporting. Journal of Accounting and Economics 36: 337-386. 
Hirst, D., and P. Hopkins. 1998. Comprehensive income reporting and analysts' valuation judgments. Journal of Accounting Research 36: 47-75.

Hirst, D., L. Koonce, and S. Venkataraman. 2007. How disaggregation enhances the credibility of management earnings forecasts. Journal of Accounting Research 45: 811-837.

Hirst, D., L. Koonce, and S. Venkataraman. 2008. Management earnings forecasts: A review and framework. Accounting Horizons 22: 315-338.

Hopkins, P., R. Houston, and M. Peters. 2000. Purchase, pooling, and equity analysts' valuation judgments. The Accounting Review 75: 257-281.

Hosmer, D., and S. Lemeshow. 2000. Applied logistic regression. John Wiley, New Jersey.

Huberman, G., and T. Regev. 2001. Contagious speculation and a cure for cancer: A nonevent that made stock prices soar. Journal of Finance 56: 387-396.

Hutton, A., and P. Stocken. 2009. Prior forecasting accuracy and investor reaction to management earnings forecasts. Working paper, Boston College.

Jennings, R. 1987. Unsystematic security price movements, management earnings forecasts, and revisions in consensus analyst earnings forecasts. Journal of Accounting Research 25: 90-110.

Kim, K., S. Pandit, and C. Wasley. 2012. Aggregate uncertainty and management earnings forecasts. Working paper, University of Illinois at Chicago and University of Rochester.

King, R., G. Pownall, and G. Waymire. 1990. Expectations adjustment via timely earnings forecast disclosure: Review, synthesis, and suggestions for future research. Journal of Accounting Literature 9: 113-44.

Koch, A., and J. Park. 2011. Consistent earnings growth and the credibility of management forecasts. Working paper, University of Virginia and Old Dominion University.

Kothari, S., S. Shu, and P. Wysocki. 2009a. Do managers withhold bad news? Journal of Accounting Research 47: 241-276.

Kothari, S., X. Li, and J. Short. 2009b. The effects of disclosures by management, analysts, and business press on cost of capital, return volatility, and analysts forecasts: A study using content analysis. The Accounting Review 84: 1639-1670.

Kross, W., and I. Suk. 2012. Does Regulation FD work? Evidence from analysts' reliance on public disclosure. Journal of Accounting and Economics 53: 225-248.

Leone, A., M. Minutti-Meza, and C. Wasley. 2012. Influential observations and inference in accounting research. Working paper, University of Miami and University of Rochester. 
Lennox, C. J. Francis, and Z. Wang. 2012. Selection models in accounting research. The Accounting Review 87: 589-616.

Lerman, A. 2011. Individual investors' attention to accounting information: Message board discussions. Working paper, Yale University.

Li, K., and N. Prabhala. 2007. Self-selection models in corporate finance. In Handbook of Corporate Finance: Empirical Corporate Finance, edited by B. E. Eckso, 37-86. Amsterdam, The Netherlands: Elsevier Science B.V.

Li, E., K. Ramesh, and M. Shen. 2011. The roles of newswires in screening and disseminating value-relevant information in periodic SEC reports. The Accounting Review 86: 669-701.

Mercer, M. 2004. How do investors assess the credibility of management disclosures? Accounting Horizons 18: 185-196.

Merkley, K., L. Bamber, and T. Christensen. 2012. Detailed management earnings forecasts: Do analysts listen? Forthcoming in Review of Accounting Studies.

Merton, R. 1987. A simple model of capital market equilibrium with incomplete information. Journal of Finance 42: 483-510.

Ng, J., I. Tuna, and R. Verdi. 2013. Management forecast credibility and underreaction to news. Forthcoming in Review of Accounting Studies.

Payne, J., and W. Thomas. 2003. The implications of using stock-split adjusted I/B/E/S data in empirical research. The Accounting Review 78: 1049-1067.

Penman, S. 1980. An empirical investigation of the voluntary disclosure of corporate earnings forecasts. Journal of Accounting Research 18: 132-160.

Petersen, M. 2009. Estimating standard errors in finance panel data sets: Comparing approaches. The Review of Financial Studies 22: 435-480.

Plumlee, M. 2003. The effect of information complexity on analysts' use of that information. The Accounting Review 78: 275-296.

Pownall, G., C. Wasley, and G. Waymire. 1993. The stock price effects of alternative types of management earnings forecasts. The Accounting Review 68: 896-912.

Rees, L., N. Sharp, and B. Twedt. 2012. Who's heard on the street? Determinants and consequences of financial analyst coverage in the business press. Working paper, Texas A\&M University.

Rogers, J., D. Skinner, and S. Zechman. 2013. The role of the media in disseminating insider trading news. Working paper, University of Chicago. 
Rogers, J., and P. Stocken. 2005. Credibility of management forecasts. The Accounting Review 80: $1233-1260$.

Rogers, J., and A. Van Buskirk. 2012. Bundled forecasts in empirical accounting research. Forthcoming in the Journal of Accounting and Economics.

Skinner, D. 1994. Why firms voluntarily disclose bad news. Journal of Accounting Research 32: 38-60.

Solomon, D. and E. Soltes. 2012. Managerial control of business press coverage. Working paper, University of Southern California and Harvard University.

Soltes, E. 2010. Disseminating firm disclosures. Working paper, Harvard University.

Tetlock, P. 2007. Giving content to investor sentiment: The role of media in the stock market. Journal of Finance 62: 1139-1168.

Tetlock, P. 2010. Does public financial news resolve asymmetric information? Review of Financial Studies 23: 3520-3557.

Tetlock, P. 2011. All the news that's fit to reprint: Do investors react to stale information? Review of Financial Studies 24: 1481-1512.

Tucker, J. 2011. Selection bias and econometric remedies in accounting and finance research. Journal of Accounting Literature 29: 31-57.

Williams, P. 1996. The relation between a prior earnings forecast by management and analyst response to a current management forecast. The Accounting Review 71: 103-115.

Yang, H. 2012. Capital market consequences of managers' voluntary disclosure styles. Journal of Accounting and Economics 53: 167-184. 


\section{APPENDIX A}

\section{FIGURES AND TABLES}

FIGURE 1

FRAMEWORK FOR ANALYZING THE MARKET CONSEQUENCES OF MANAGEMENT EARNINGS GUIDANCE

\begin{tabular}{|c|c|c|c|c|}
\hline $\begin{array}{c}\text { Managerial } \\
\text { Goal }\end{array}$ & $\begin{array}{c}\text { Managerial } \\
\text { Action }\end{array}$ & $\begin{array}{l}\text { Dissemination } \\
\text { of Information }\end{array}$ & $\begin{array}{c}\text { Market Assessment } \\
\text { of Information }\end{array}$ & $\begin{array}{l}\text { Market Reaction } \\
\text { to Information }\end{array}$ \\
\hline $\begin{array}{l}\text { Align market } \\
\text { expectations with } \\
\text { managers' private } \\
\text { information. }\end{array}$ & $\begin{array}{l}\text { Managers } \\
\text { issue earnings } \\
\text { guidance. }\end{array}$ & $\begin{array}{l}\text { Guidance is } \\
\text { communicated } \\
\text { to market } \\
\text { participants. }\end{array}$ & $\begin{array}{l}\text { Market participants } \\
\text { evalute information } \\
\text { content and } \\
\text { credibility. }\end{array}$ & $\begin{array}{l}\text { Market participants } \\
\text { align expectations } \\
\text { with guidance. }\end{array}$ \\
\hline
\end{tabular}


FIGURE 2

TIMELINE OF PRESS COVERAGE OF MANAGEMENT EARNINGS GUIDANCE

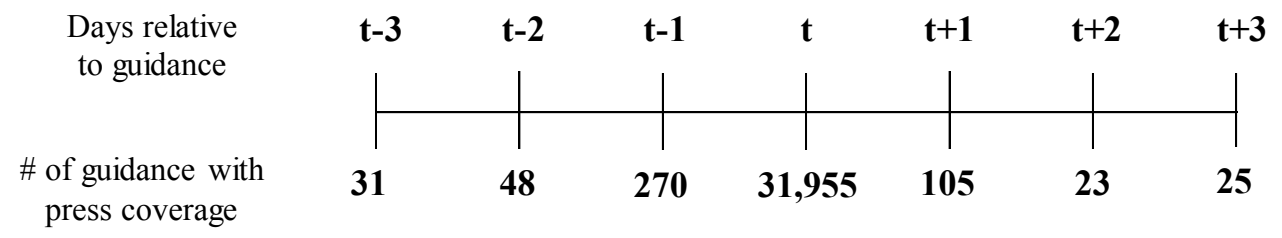

This figure illustrates the mapping of guidance press coverage from the DJ news archives into guidance observations obtained from First Call's Company Issued Guidance database. The total number of guidance is 66,598. Of these 66,598 management earnings forecasts, 31,955 had press coverage on the day of the guidance (day t), while only 502 had press coverage on any of the six days surrounding the day of the guidance. 
FIGURE 3

HISTOGRAM OF WITHIN-FIRM VARIATION IN PRESS COVERAGE OF MANAGEMENT EARNINGS GUIDANCE

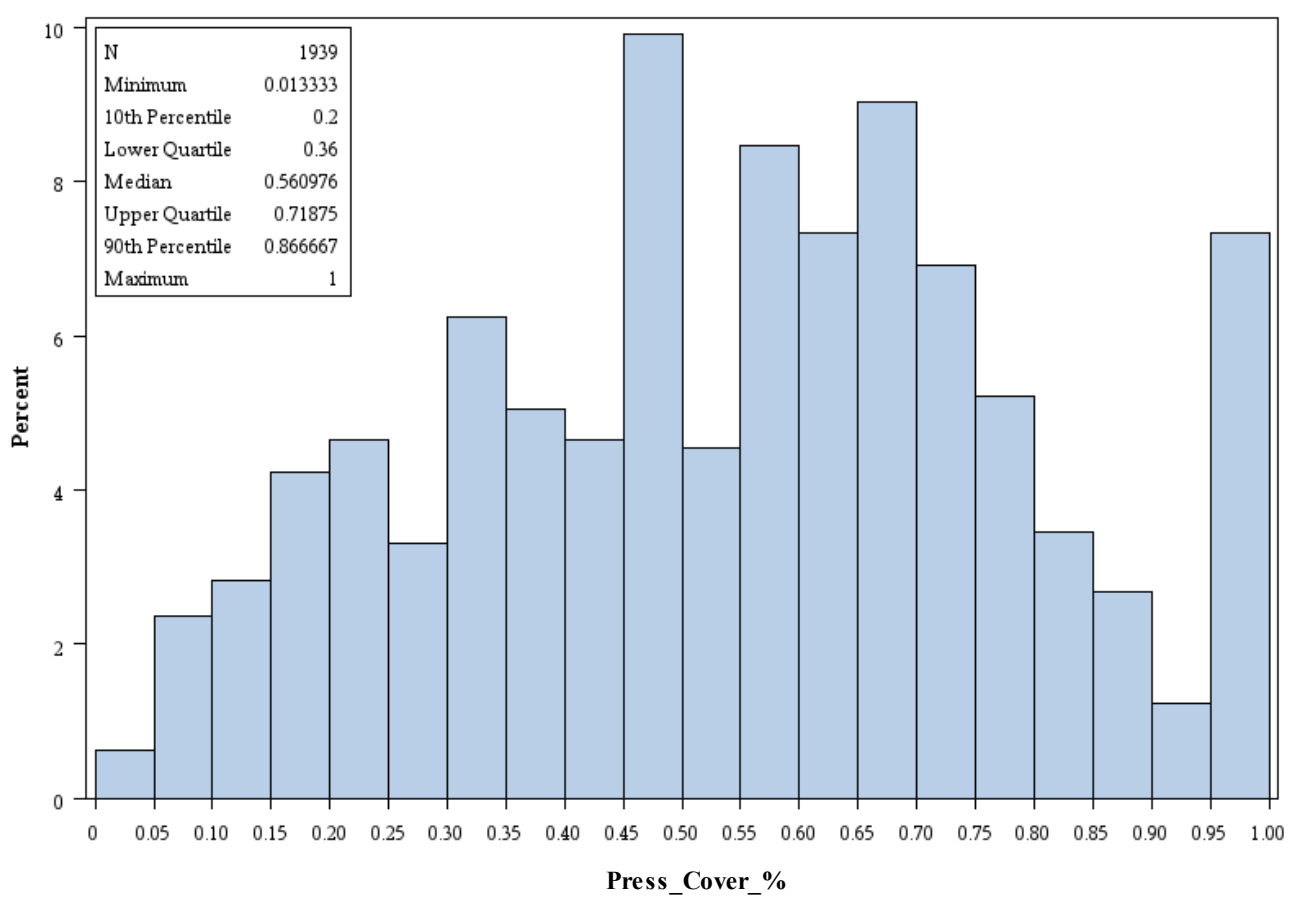

This figure illustrates the degree of within-firm variation in guidance press coverage. The total number of unique firms in the sample is 2,914. Of these 2,914 firms, 1,939 received guidance press coverage at least once during the sample period. For these 1,939 firms, the above histogram displays the frequency with which their guidance received press coverage. The variable on the x-axis, Press_Cover_\%, represents the percentage of the firm's guidance that received press coverage. The $y$-axis measures the percentage of the 1,939 firms with a given value of Press_Cover_\%. 
TABLE 1

SAMPLE SELECTION AND COMPOSITION

Panel A: Sample Selection

\# of Forecasts

Total unique quantitative management earnings guidance issued during 2001-2010 $\quad$ 89,725

Less:

Guidance issued after the forecasting period end (earnings pre-announcements) $\quad(7,702)$

Guidance issued by firms without sufficient CRSP/Compustat data

Guidance issued by firms without sufficient analyst coverage and actual earnings

Final sample of all guidance

66,598

Less:

Bundled guidance

Multiple guidance issued on the same day

Final sample of stand-alone guidance

9,286

Panel B: Sample Composition by Year and Press Coverage

\begin{tabular}{lcccc}
\hline Year & $\begin{array}{c}\text { Number of forecasts } \\
(\text { Total = 66,598) }\end{array}$ & $\begin{array}{c}\text { Percentage of guidance } \\
\text { with press coverage }\end{array}$ & $\begin{array}{c}\text { Unique firms } \\
\text { (Total=2,914) }\end{array}$ & $\begin{array}{c}\text { Percentage of firms with } \\
\text { guidance press coverage }\end{array}$ \\
\hline 2001 & 5,222 & $35.4 \%$ & 1,447 & $45.7 \%$ \\
2002 & 6,520 & $44.7 \%$ & 1,432 & $58.5 \%$ \\
2003 & 6,642 & $44.5 \%$ & 1,407 & $61.3 \%$ \\
2004 & 7,779 & $47.6 \%$ & 1,511 & $65.7 \%$ \\
2005 & 7,551 & $47.5 \%$ & 1,462 & $63.7 \%$ \\
2006 & 7,761 & $46.5 \%$ & 1,502 & $66.0 \%$ \\
2007 & 7,216 & $52.6 \%$ & 1,389 & $70.6 \%$ \\
2008 & 6,724 & $53.5 \%$ & 1,221 & $72.2 \%$ \\
2009 & 5,389 & $53.7 \%$ & 1,048 & $73.4 \%$ \\
2010 & 5,794 & $52.6 \%$ & 1,055 & $71.3 \%$ \\
Average & 6,660 & $47.9 \%$ & 1,347 & $64.8 \%$ \\
\hline
\end{tabular}


TABLE 1 (CONTINUED)

Panel C: Sample Composition by Industry and Press Coverage

\begin{tabular}{lcc}
\hline Industry: & $\begin{array}{c}\text { Number of forecasts } \\
\text { (Total = 66,598) }\end{array}$ & $\begin{array}{c}\text { Percentage of guidance } \\
\text { with press coverage }\end{array}$ \\
\hline Consumer NonDurables & 4,670 & $49.3 \%$ \\
Consumer Durables & 1,787 & $48.3 \%$ \\
Manufacturing & 6,968 & $54.5 \%$ \\
Energy & 775 & $46.6 \%$ \\
Chemicals & 1,748 & $57.3 \%$ \\
Business Equipment & 14,926 & $41.1 \%$ \\
Telecom & 683 & $39.4 \%$ \\
Utilities & 3,291 & $45.0 \%$ \\
Wholesale and Retail & 11,389 & $55.1 \%$ \\
Healthcare & 6,611 & $45.2 \%$ \\
Finance & 5,007 & $41.7 \%$ \\
Other & 8,743 & $50.2 \%$ \\
Average & 5,550 & $47.8 \%$ \\
\hline
\end{tabular}

Industry groupings are based on the Fama-French 12-industry classification scheme.

Panel D: Sample Composition by Weekday and Press Coverage

\begin{tabular}{lcc}
\hline Industry: & $\begin{array}{c}\text { Number of forecasts } \\
(\text { Total = 66,598) }\end{array}$ & $\begin{array}{c}\text { Percentage of guidance } \\
\text { with press coverage }\end{array}$ \\
\hline Monday & 8,341 & $47.2 \%$ \\
Tuesday & 15,817 & $46.0 \%$ \\
Wednesday & 16,882 & $48.2 \%$ \\
Thursday & 21,684 & $49.6 \%$ \\
Friday & 3,874 & $47.8 \%$ \\
Average & 13,320 & $47.8 \%$ \\
\hline
\end{tabular}


TABLE 2

DETERMINANTS OF PRESS COVERAGE OF MANAGEMENT EARNINGS GUIDANCE

Panel A: Descriptive Statis tics

\begin{tabular}{lccccc}
\hline Variable & Mean & Std. Dev & 25 th & Median & 75th \\
\hline Press_Cover & 0.4798 & 0.4996 & 0.0000 & 0.0000 & 1.0000 \\
Abs_Guide_News & 0.0036 & 0.0059 & 0.0005 & 0.0015 & 0.0038 \\
Bad_Guide_News & 0.4874 & 0.4998 & 0.0000 & 0.0000 & 1.0000 \\
Guide_Reputation & 0.2072 & 0.4145 & 0.0000 & 0.2174 & 0.4667 \\
Annual & 0.5785 & 0.4938 & 0.0000 & 1.0000 & 1.0000 \\
Horizon & 0.4198 & 0.3293 & 0.1699 & 0.2219 & 0.6795 \\
Range & 0.8658 & 0.3409 & 1.0000 & 1.0000 & 1.0000 \\
Bundled & 0.7474 & 0.4345 & 0.0000 & 1.0000 & 1.0000 \\
Multiple & 0.5169 & 0.4997 & 0.0000 & 1.0000 & 1.0000 \\
P_Guide_Press_Cover & 0.4420 & 0.4966 & 0.0000 & 0.0000 & 1.0000 \\
P_Month_Press_Cover & 0.1689 & 0.1558 & 0.0667 & 0.1333 & 0.2333 \\
SP1500 & 0.6961 & 0.4600 & 0.0000 & 1.0000 & 1.0000 \\
Instit_Own & 0.6815 & 0.2762 & 0.5625 & 0.7556 & 0.8819 \\
Ln_MVE & 7.4473 & 1.5778 & 6.3146 & 7.2965 & 8.4972 \\
BTM & 0.4527 & 0.2961 & 0.2481 & 0.3901 & 0.5889 \\
ROA & 0.0504 & 0.0823 & 0.0238 & 0.0533 & 0.0895 \\
Loss & 0.1717 & 0.3771 & 0.0000 & 0.0000 & 0.0000 \\
Q_ERC & 1.9724 & 1.4412 & 1.0000 & 2.0000 & 3.0000 \\
Meet_Beat_Hist & 0.7978 & 0.2664 & 0.7500 & 1.0000 & 1.0000 \\
P_Month_Abn_Ret & -0.0015 & 0.1129 & -0.0614 & -0.0008 & 0.0593 \\
P_Month_Ret_Vol & 0.0245 & 0.0142 & 0.0148 & 0.0208 & 0.0298 \\
P_Month_Turn & 0.0097 & 0.0075 & 0.0047 & 0.0075 & 0.0121 \\
Ln_Follow & 2.0404 & 0.6778 & 1.6094 & 2.0794 & 2.5649 \\
Dispersion & 0.0510 & 0.0642 & 0.0100 & 0.0300 & 0.0600 \\
After_Hours & 0.4283 & 0.4948 & 0.0000 & 0.0000 & 1.0000 \\
Other_Press_Cover & 1.4903 & 1.0453 & 0.4900 & 1.3200 & 2.3500 \\
\hline
\end{tabular}

The sample is comprised of 66,598 management earnings guidance observations. See Appendix B for variable definitions. 
TABLE 2 (CONTINUED)

Panel B: Logistic Regression Analysis

\begin{tabular}{|c|c|c|c|c|}
\hline $\begin{array}{l}\text { Dependent variable: } \\
\text { Press_Cover } \\
\end{array}$ & $\begin{array}{l}\text { Expected } \\
\text { Sign } \\
\end{array}$ & Coefficient & P-Value & Odds Ratio \\
\hline Abs_Guide_News & + & $15.359 * * *$ & $(0.001)$ & 1.095 \\
\hline Bad_Guide_News & $?$ & $-0.081 * * *$ & $(0.001)$ & 0.923 \\
\hline Guide_Reputation & $?$ & -0.005 & $(0.903)$ & 0.998 \\
\hline Annual & $?$ & $-0.135^{* * *}$ & $(0.001)$ & 0.874 \\
\hline Horizon & $?$ & -0.028 & $(0.478)$ & 0.991 \\
\hline Range & $?$ & $0.585^{* * *}$ & $(0.001)$ & 1.794 \\
\hline Bundled & + & $0.396 * * *$ & $(0.001)$ & 1.486 \\
\hline Multiple & + & $0.470 * * *$ & $(0.001)$ & 1.600 \\
\hline P_Guide_Press_Cover & + & $1.228 * * *$ & $(0.001)$ & 3.414 \\
\hline P_Month_Press_Cover & + & $1.495 * * *$ & $(0.001)$ & 1.262 \\
\hline $\mathrm{SP} 1500$ & + & $0.190 * * *$ & $(0.001)$ & 1.209 \\
\hline Instit_Own & + & $0.182 * *$ & $(0.040)$ & 1.052 \\
\hline Ln_MVE & + & $-0.105^{* * *}$ & $(0.001)$ & 0.848 \\
\hline BTM & $?$ & -0.104 & $(0.124)$ & 0.970 \\
\hline ROA & $?$ & 0.334 & $(0.122)$ & 1.028 \\
\hline Loss & $?$ & -0.056 & $(0.146)$ & 0.946 \\
\hline Q_ERC & + & $0.020 * *$ & $(0.046)$ & 1.029 \\
\hline Meet_Beat_Hist & + & $0.114^{* *}$ & $(0.032)$ & 1.031 \\
\hline P_Month_Abn_Ret & $?$ & -0.056 & $(0.555)$ & 0.994 \\
\hline P_Month_Ret_Vol & $?$ & $-6.996 * * *$ & $(0.001)$ & 0.906 \\
\hline P_Month_Turn & $?$ & -3.865 & $(0.181)$ & 0.972 \\
\hline Ln_Follow & + & 0.008 & $(0.824)$ & 1.005 \\
\hline Dispersion & $?$ & 0.395 & $(0.102)$ & 1.026 \\
\hline After_Hours & - & 0.023 & $(0.574)$ & 1.023 \\
\hline Other_Press_Cover & - & $-0.063^{* * *}$ & $(0.003)$ & 0.936 \\
\hline Industry FE & & Included & & \\
\hline Year, Month, Day of Week FE & & Included & & \\
\hline Pseudo $\mathrm{R}^{2}$ & & $11.6 \%$ & & \\
\hline Area Under Roc Curve & & 0.724 & & \\
\hline Hosmer-Lemeshow P-Value & & 0.409 & & \\
\hline No. Obs. & & 66,598 & & \\
\hline
\end{tabular}

This table examines the determinants of business press coverage of management earnings guidance.

See Appendix B for variable definitions. All continuous variables, except stock returns, are winsorized at the first and 99th percentiles to alleviate the effects of outliers on the analysis.

P-values are reported in parentheses based on z-statistics calculated using White's (1980) heteroscedasticity robust standard errors clustered by firm to control for dependency in the error terms (Petersen 2009; Gow et al. 2010). Industry, year, month, and day of the week fixed effects are also included in the models (coefficients not reported).

Odds ratios are given for a one standard deviation increase in the continuous independent variables, and a change from 0 to 1 in the indicator variables.

$*, * *, * * *$ indicate statistical significance at the $0.10,0.05$, and 0.01 levels, respectively, using a two-tailed test. 
TABLE 3

COVARIATE BALANCE BETWEEN MATCHED PAIRS

\begin{tabular}{|c|c|c|c|c|c|c|}
\hline \multirow[b]{2}{*}{ Variable } & \multicolumn{2}{|c|}{ Covered } & \multicolumn{2}{|c|}{ Non-Covered } & \multicolumn{2}{|c|}{$\begin{array}{c}\text { Difference } \\
(\text { Bold }=\text { Sig. at } .05 \text { level })\end{array}$} \\
\hline & Mean & Median & Mean & Median & Mean & Median \\
\hline Abs_Guide_News & 0.0046 & 0.0019 & 0.0046 & 0.0011 & 0.0000 & 0.0008 \\
\hline Bad_Guide_News & 0.6307 & 1.0000 & 0.6222 & 1.0000 & 0.0084 & $\mathrm{~N} / \mathrm{A}$ \\
\hline Guide_Reputation & 0.2348 & 0.2500 & 0.2388 & 0.2500 & -0.0040 & 0.0000 \\
\hline Annual & 0.5934 & 1.0000 & 0.5774 & 1.0000 & 0.0160 & N/A \\
\hline Horizon & 0.3851 & 0.2356 & 0.3741 & 0.2356 & 0.0110 & 0.0000 \\
\hline Range & 0.8671 & 1.0000 & 0.8663 & 1.0000 & 0.0008 & N/A \\
\hline P_Guide_Press_Cover & 0.4294 & 0.0000 & 0.4562 & 0.0000 & -0.0268 & $\mathrm{~N} / \mathrm{A}$ \\
\hline P_Month_Press_Cover & 0.1967 & 0.1667 & 0.2023 & 0.1667 & -0.0056 & 0.0000 \\
\hline SP 1500 & 0.7391 & 1.0000 & 0.7459 & 1.0000 & -0.0068 & $\mathrm{~N} / \mathrm{A}$ \\
\hline Instit_Own & 0.6578 & 0.7219 & 0.6544 & 0.7279 & 0.0034 & -0.0061 \\
\hline Ln_MVE & 7.5953 & 7.4376 & 7.6387 & 7.5035 & -0.0434 & -0.0660 \\
\hline BTM & 0.4588 & 0.4035 & 0.4592 & 0.3889 & -0.0004 & 0.0146 \\
\hline ROA & 0.0564 & 0.0551 & 0.0581 & 0.0562 & -0.0017 & -0.0012 \\
\hline Loss & 0.1513 & 0.0000 & 0.1445 & 0.0000 & 0.0068 & $\mathrm{~N} / \mathrm{A}$ \\
\hline Q_ERC & 1.9528 & 2.0000 & 1.9772 & 2.0000 & -0.0244 & 0.0000 \\
\hline Meet_Beat_Hist & 0.7772 & 0.7500 & 0.7833 & 1.0000 & -0.0061 & -0.2500 \\
\hline P_Month_Abn_Ret & -0.0079 & -0.0089 & -0.0076 & -0.0071 & -0.0003 & -0.0018 \\
\hline P_Month_Ret_Vol & 0.0247 & 0.0213 & 0.0243 & 0.0207 & 0.0004 & 0.0006 \\
\hline P_Month_Turn & 0.0101 & 0.0077 & 0.0102 & 0.0077 & -0.0001 & 0.0001 \\
\hline Ln_Follow & 2.1132 & 2.1972 & 2.1271 & 2.1972 & -0.0139 & 0.0000 \\
\hline Dispersion & 0.0525 & 0.0300 & 0.0522 & 0.0300 & 0.0003 & 0.0000 \\
\hline After_Hours & 0.3281 & 0.0000 & 0.3221 & 0.0000 & 0.0060 & N/A \\
\hline Other_Press_Cover & 0.6905 & 0.4100 & 0.6827 & 0.4000 & 0.0078 & 0.0100 \\
\hline
\end{tabular}

This table presents a comparison of the means and medians of the variables in equation (1) for the standalone guidance sample after propensity-score matching (4,998 observations).

See Appendix B for variable definitions.

Differences in bold are significant at the $\alpha=0.05$ level, using two-tailed $t$-tests of means and Wilcoxon ranksum tests of medians for continuous variables, and $\chi^{2}$ tests of equal proportions for indicator variables. 
TABLE 4

DESCRIPTIVE STATISTICS BEFORE AND AFTER MATCHING

\begin{tabular}{|c|c|c|c|c|c|c|c|c|c|c|}
\hline \multirow[b]{2}{*}{ Variable } & \multicolumn{4}{|c|}{ Before Matching } & \multicolumn{3}{|c|}{ After Propensity-Score Matching } & \multicolumn{3}{|c|}{ After Within-Firm Matching } \\
\hline & $\begin{array}{c}\text { All Obs. } \\
\text { Mean }\end{array}$ & $\begin{array}{c}\text { Covered } \\
\text { Mean }\end{array}$ & $\begin{array}{c}\text { Non-Covered } \\
\text { Mean }\end{array}$ & Diff. & $\begin{array}{c}\text { Covered } \\
\text { Mean }\end{array}$ & $\begin{array}{c}\text { Non-Covered } \\
\text { Mean }\end{array}$ & Diff. & $\begin{array}{c}\text { Covered } \\
\text { Mean }\end{array}$ & $\begin{array}{c}\text { Non-Covered } \\
\text { Mean }\end{array}$ & Diff. \\
\hline Abn_Return $(0,1)$ & -0.0107 & -0.0128 & -0.0096 & -0.0032 & -0.0134 & -0.0122 & -0.0012 & -0.0042 & -0.0058 & 0.0017 \\
\hline Fraction & 0.2871 & 0.4324 & 0.2121 & 0.2203 & 0.4207 & 0.2613 & 0.1593 & 0.4044 & 0.2136 & 0.1908 \\
\hline Abs_Abn_Return $(0,1)$ & 0.0542 & 0.0614 & 0.0504 & 0.0109 & 0.0615 & 0.0513 & 0.0102 & 0.0597 & 0.0439 & 0.0158 \\
\hline Guide_News & -0.0023 & -0.0026 & -0.0021 & -0.0004 & -0.0024 & -0.0027 & 0.0002 & -0.0022 & -0.0014 & -0.0008 \\
\hline Abs_Guide_News & 0.0043 & 0.0049 & 0.0040 & 0.0009 & 0.0046 & 0.0046 & 0.0000 & 0.0044 & 0.0032 & 0.0012 \\
\hline Guide_Reputation & 0.2167 & 0.2387 & 0.2053 & 0.0334 & 0.2348 & 0.2388 & -0.0040 & 0.2112 & 0.2283 & -0.0171 \\
\hline Horizon & 0.3960 & 0.3736 & 0.4076 & -0.0340 & 0.3851 & 0.3741 & 0.0110 & 0.4037 & 0.3835 & 0.0201 \\
\hline Range & 0.8374 & 0.8895 & 0.8105 & 0.0790 & 0.8671 & 0.8663 & 0.0008 & 0.8757 & 0.8403 & 0.0354 \\
\hline P_Month_Press_Cover & 0.2035 & 0.2021 & 0.2042 & -0.0021 & 0.1967 & 0.2023 & -0.0056 & 0.2228 & 0.2375 & -0.0148 \\
\hline Instit_Own & 0.6628 & 0.6692 & 0.6595 & 0.0097 & 0.6578 & 0.6544 & 0.0034 & 0.6699 & 0.6804 & -0.0106 \\
\hline Ln_MVE & 7.7009 & 7.5648 & 7.7710 & -0.2062 & 7.5953 & 7.6387 & -0.0434 & 7.8994 & 7.9080 & -0.0086 \\
\hline BTM & 0.4617 & 0.4594 & 0.4628 & -0.0034 & 0.4588 & 0.4592 & -0.0004 & 0.4291 & 0.4351 & -0.0060 \\
\hline Ln_Follow & 2.1550 & 2.1180 & 2.1741 & -0.0561 & 2.1132 & 2.1271 & -0.0139 & 2.2498 & 2.2367 & 0.0131 \\
\hline Dispersion & 0.0543 & 0.0536 & 0.0546 & -0.0011 & 0.0525 & 0.0522 & 0.0003 & 0.0548 & 0.0530 & 0.0019 \\
\hline
\end{tabular}

This table presents descriptive statistics for the variables used in the regressions examining the market reaction to press coverage of management earnings guidance. The descriptive statistics are provided for the full sample (9,286 observations), the propensity-score matched sample (4,998 observations), and the within-firm matched sample (2,092 observations) of stand-alone guidance. Propensity-scores are calculated using equation (1).

See Appendix B for variable definitions.

Differences in bold are significant at the $\alpha=0.05$ level, using a two-tailed $t$-test of means for continuous variables and a $\chi^{2}$ test of equal proportions for indicator variables. 
TABLE 5

MARKET REACTION TO PRESS COVERAGE OF MANAGEMENT EARNINGS GUIDANCE

Panel A: Investor Reaction

\begin{tabular}{|c|c|c|c|c|}
\hline \multirow{2}{*}{$\begin{array}{l}\text { Dependent variable: } \\
\text { Abn_Return }(0,1)\end{array}$} & \multicolumn{2}{|c|}{ Propensity-Score Matched Sample } & \multicolumn{2}{|c|}{ Within-Firm Matched Sample } \\
\hline & $\begin{array}{l}\text { Stand-Alone } \\
\text { Guidance }\end{array}$ & All Guidance & $\begin{array}{l}\text { Stand-Alone } \\
\text { Guidance }\end{array}$ & All Guidance \\
\hline Guide_News & $\begin{array}{c}2.381 * * * \\
(0.001)\end{array}$ & $\begin{array}{c}2.741 * * * \\
(0.001)\end{array}$ & $\begin{array}{c}2.328 * * * \\
(0.001)\end{array}$ & $\begin{array}{c}2.523 * * * \\
(0.001)\end{array}$ \\
\hline Press_Cover & $\begin{array}{c}0.009 * * * \\
(0.001)\end{array}$ & $\begin{array}{c}0.001 \\
(0.161)\end{array}$ & $\begin{array}{c}0.014 * * * \\
(0.001)\end{array}$ & $\begin{array}{c}0.005^{* * * *} \\
(0.001)\end{array}$ \\
\hline Guide_News*Press_Cover & $\begin{array}{c}2.144 * * * \\
(0.001)\end{array}$ & $\begin{array}{c}1.442 * * * \\
(0.001)\end{array}$ & $\begin{array}{l}2.006^{* *} \\
(0.015)\end{array}$ & $\begin{array}{c}1.424 * * * \\
(0.001)\end{array}$ \\
\hline Fraction & $\begin{array}{c}-0.039 * * * \\
(0.001)\end{array}$ & $\begin{array}{c}-0.009 * * * \\
(0.001)\end{array}$ & $\begin{array}{c}-0.034 * * * \\
(0.001)\end{array}$ & $\begin{array}{c}-0.005^{* *} \\
(0.028)\end{array}$ \\
\hline Guide_Reputation & $\begin{array}{c}0.000 \\
(0.984)\end{array}$ & $\begin{array}{l}-0.002 \\
(0.199)\end{array}$ & $\begin{array}{c}0.000 \\
(0.940)\end{array}$ & $\begin{array}{l}-0.001 \\
(0.507)\end{array}$ \\
\hline Horizon & $\begin{array}{l}0.010^{* * * *} \\
(0.005)\end{array}$ & $\begin{array}{c}0.005^{* * * *} \\
(0.001)\end{array}$ & $\begin{array}{l}0.011 * * \\
(0.038)\end{array}$ & $\begin{array}{c}0.001 \\
(0.496)\end{array}$ \\
\hline Range & $\begin{array}{l}-0.005 \\
(0.123)\end{array}$ & $\begin{array}{l}-0.001 \\
(0.650)\end{array}$ & $\begin{array}{l}-0.005 \\
(0.260)\end{array}$ & $\begin{array}{c}0.003 \\
(0.123)\end{array}$ \\
\hline P_Month_Press_Cover & $\begin{array}{c}0.001 \\
(0.889)\end{array}$ & $\begin{array}{c}0.006 \\
(0.149)\end{array}$ & $\begin{array}{l}-0.013 \\
(0.307)\end{array}$ & $\begin{array}{l}0.010^{*} \\
(0.091)\end{array}$ \\
\hline Instit_Own & $\begin{array}{l}-0.001 \\
(0.775)\end{array}$ & $\begin{array}{l}-0.002 \\
(0.443)\end{array}$ & $\begin{array}{l}-0.000 \\
(0.989)\end{array}$ & $\begin{array}{c}0.004 \\
(0.184)\end{array}$ \\
\hline Ln_MVE & $\begin{array}{c}0.001 \\
(0.605)\end{array}$ & $\begin{array}{l}-0.000 \\
(0.966)\end{array}$ & $\begin{array}{l}-0.001 \\
(0.460)\end{array}$ & $\begin{array}{l}-0.002 * \\
(0.054)\end{array}$ \\
\hline BTM & $\begin{array}{l}0.010 * * \\
(0.046)\end{array}$ & $\begin{array}{c}0.010 * * * \\
(0.001)\end{array}$ & $\begin{array}{c}0.003 \\
(0.709)\end{array}$ & $\begin{array}{c}0.012 * * * \\
(0.001)\end{array}$ \\
\hline Ln_Follow & $\begin{array}{c}0.000 \\
(0.960)\end{array}$ & $\begin{array}{l}-0.001 \\
(0.395)\end{array}$ & $\begin{array}{l}-0.000 \\
(0.975)\end{array}$ & $\begin{array}{c}0.002 \\
(0.229)\end{array}$ \\
\hline Dispersion & $\begin{array}{c}0.021 \\
(0.199)\end{array}$ & $\begin{array}{c}0.022 * * \\
(0.047)\end{array}$ & $\begin{array}{c}0.010 \\
(0.695)\end{array}$ & $\begin{array}{c}0.004 \\
(0.779)\end{array}$ \\
\hline Industry FE & Included & Included & Included & Included \\
\hline Year, Month, Day of Week FE & Included & Included & Included & Included \\
\hline Adj. $R^{2}$ & $16.0 \%$ & $8.2 \%$ & $15.3 \%$ & $7.3 \%$ \\
\hline No. Obs. & 4,998 & 41,258 & 2,092 & 16,634 \\
\hline
\end{tabular}


TABLE 5 (CONTINUED)

Panel B: Analyst Reaction

\begin{tabular}{|c|c|c|c|c|}
\hline \multirow{2}{*}{$\begin{array}{l}\text { Dependent variable: } \\
\text { Fraction }\end{array}$} & \multicolumn{2}{|c|}{ Propensity-Score Matched Sample } & \multicolumn{2}{|c|}{ Within-Firm Matched Sample } \\
\hline & $\begin{array}{l}\text { Stand-Alone } \\
\text { Guidance }\end{array}$ & All Guidance & $\begin{array}{l}\text { Stand-Alone } \\
\text { Guidance }\end{array}$ & All Guidance \\
\hline Abs_Guide_News & $\begin{array}{c}6.080 * * * \\
(0.001)\end{array}$ & $\begin{array}{c}2.943 * * * \\
(0.002)\end{array}$ & $\begin{array}{c}3.242 * \\
(0.075)\end{array}$ & $\begin{array}{l}2.642^{*} \\
(0.088)\end{array}$ \\
\hline Press_Cover & $\begin{array}{c}0.128 * * * \\
(0.001)\end{array}$ & $\begin{array}{c}0.040 * * * \\
(0.001)\end{array}$ & $\begin{array}{c}0.127 * * * \\
(0.001)\end{array}$ & $\begin{array}{c}0.043 * * * \\
(0.001)\end{array}$ \\
\hline Abs_Guide_News*Press_Cover & $\begin{array}{c}5.412 * * * \\
(0.001)\end{array}$ & $\begin{array}{c}4.364 * * * \\
(0.001)\end{array}$ & $\begin{array}{c}9.138 * * * \\
(0.001)\end{array}$ & $\begin{array}{c}4.731 * * * \\
(0.001)\end{array}$ \\
\hline Abs_Abn_Return $(0,1)$ & $\begin{array}{c}1.107 * * * \\
(0.001)\end{array}$ & $\begin{array}{c}0.907 * * * \\
(0.001)\end{array}$ & $\begin{array}{c}0.909 * * * \\
(0.001)\end{array}$ & $\begin{array}{c}0.844^{* * * *} \\
(0.001)\end{array}$ \\
\hline Guide_Reputation & $\begin{array}{c}0.037 * * * \\
(0.003)\end{array}$ & $\begin{array}{c}0.028 * * * \\
(0.001)\end{array}$ & $\begin{array}{c}0.047 * * * \\
(0.006)\end{array}$ & $\begin{array}{l}0.023 * * \\
(0.031)\end{array}$ \\
\hline Horizon & $\begin{array}{c}-0.145^{* * * *} \\
(0.001)\end{array}$ & $\begin{array}{c}-0.110^{* * *} \\
(0.001)\end{array}$ & $\begin{array}{c}-0.133^{* * *} \\
(0.001)\end{array}$ & $\begin{array}{c}-0.133^{* * * *} \\
(0.001)\end{array}$ \\
\hline Range & $\begin{array}{c}0.047 * * * \\
(0.001)\end{array}$ & $\begin{array}{l}0.012^{*} \\
(0.085)\end{array}$ & $\begin{array}{c}0.022 \\
(0.283)\end{array}$ & $\begin{array}{c}0.026^{* *} \\
(0.012)\end{array}$ \\
\hline P_Month_Press_Cover & $\begin{array}{c}-0.232 * * * \\
(0.001)\end{array}$ & $\begin{array}{c}-0.200^{* * * *} \\
(0.001)\end{array}$ & $\begin{array}{c}-0.160 * * * \\
(0.002)\end{array}$ & $\begin{array}{c}-0.158 * * * \\
(0.001)\end{array}$ \\
\hline Instit_Own & $\begin{array}{c}0.017 \\
(0.392)\end{array}$ & $\begin{array}{c}0.039 * * * \\
(0.001)\end{array}$ & $\begin{array}{l}-0.008 \\
(0.787)\end{array}$ & $\begin{array}{c}0.044 * * * \\
(0.005)\end{array}$ \\
\hline Ln_MVE & $\begin{array}{c}0.004 \\
(0.471)\end{array}$ & $\begin{array}{c}0.024 * * * \\
(0.001)\end{array}$ & $\begin{array}{l}-0.011 \\
(0.179)\end{array}$ & $\begin{array}{c}0.019 * * * \\
(0.001)\end{array}$ \\
\hline BTM & $\begin{array}{l}-0.039 * * \\
(0.039)\end{array}$ & $\begin{array}{c}-0.021 * * \\
(0.041)\end{array}$ & $\begin{array}{l}-0.022 \\
(0.452)\end{array}$ & $\begin{array}{c}-0.041^{* * * *} \\
(0.005)\end{array}$ \\
\hline Ln_Follow & $\begin{array}{c}0.014 \\
(0.221)\end{array}$ & $\begin{array}{c}-0.027 * * * \\
(0.001)\end{array}$ & $\begin{array}{l}0.031 * \\
(0.081)\end{array}$ & $\begin{array}{c}-0.023^{* * *} \\
(0.002)\end{array}$ \\
\hline Dispersion & $\begin{array}{c}-0.024 \\
(0.766)\end{array}$ & $\begin{array}{c}0.020 \\
(0.662)\end{array}$ & $\begin{array}{c}0.109 \\
(0.238)\end{array}$ & $\begin{array}{c}0.066 \\
(0.246)\end{array}$ \\
\hline Industry FE & Included & Included & Included & Included \\
\hline Year, Month, Day of Week FE & Included & Included & Included & Included \\
\hline Adj. $\mathrm{R}^{2}$ & $27.4 \%$ & $16.5 \%$ & $31.5 \%$ & $15.6 \%$ \\
\hline No. Obs. & 4,998 & 41,258 & 2,092 & 16,634 \\
\hline
\end{tabular}

This table contains the results of regressions examining the market reaction to press coverage of management earnings guidance.

See Appendix B for variable definitions. All continuous variables, except stock returns, are winsorized at the first and 99th percentiles to alleviate the effects of outliers on the analysis.

P-values are reported in parentheses based on t-statistics calculated using White's (1980) heteroscedasticity robust standard errors clustered by firm to control for dependency in the error terms (Petersen 2009; Gow et al. 2010). Industry, year, month, and day of the week fixed effects are also included in the models (coefficients not reported). $*, * *, * * *$ indicate statistical significance at the $0.10,0.05$, and 0.01 levels, respectively, using a two-tailed test. 
TABLE 6

PRICE DRIFT AND PRESS COVERAGE OF MANAGEMENT EARNINGS GUIDANCE

\begin{tabular}{|c|c|c|c|c|}
\hline \multirow{2}{*}{$\begin{array}{l}\text { Dependent variable: } \\
\text { Abn_Return }(2, t)\end{array}$} & \multicolumn{2}{|c|}{$\begin{array}{c}\text { Propensity-Score Matched Sample } \\
\text { of Stand-Alone Guidance }\end{array}$} & \multicolumn{2}{|c|}{$\begin{array}{l}\text { Within-Firm Matched Sample } \\
\text { of Stand-Alone Guidance }\end{array}$} \\
\hline & $\mathrm{t}=10$ & $\mathrm{t}=30$ & $\mathrm{t}=10$ & $\mathrm{t}=30$ \\
\hline Top_Q_Guide_News & $\begin{array}{c}0.015^{* * *} \\
(0.007)\end{array}$ & $\begin{array}{c}0.011 \\
(0.207)\end{array}$ & $\begin{array}{c}0.023 * * * \\
(0.008)\end{array}$ & $\begin{array}{l}0.027^{*} \\
(0.052)\end{array}$ \\
\hline Press_Cover & $\begin{array}{c}0.010^{* *} \\
(0.046)\end{array}$ & $\begin{array}{c}0.008 \\
(0.301)\end{array}$ & $\begin{array}{l}0.018^{*} \\
(0.056)\end{array}$ & $\begin{array}{c}0.022 \\
(0.123)\end{array}$ \\
\hline Top_Q_Guide_News*Press_Cover & $\begin{array}{c}-0.015 * * \\
(0.025)\end{array}$ & $\begin{array}{l}-0.014 \\
(0.168)\end{array}$ & $\begin{array}{c}-0.027^{* *} \\
(0.018)\end{array}$ & $\begin{array}{c}-0.039 * * \\
(0.030)\end{array}$ \\
\hline Abn_Return $(0,1)$ & $\begin{array}{l}0.050^{*} \\
(0.080)\end{array}$ & $\begin{array}{l}0.097 * * \\
(0.026)\end{array}$ & $\begin{array}{c}0.030 \\
(0.514)\end{array}$ & $\begin{array}{l}0.134^{*} \\
(0.053)\end{array}$ \\
\hline Guide_Reputation & $\begin{array}{l}-0.006^{*} \\
(0.081)\end{array}$ & $\begin{array}{l}-0.000 \\
(0.961)\end{array}$ & $\begin{array}{c}0.001 \\
(0.831)\end{array}$ & $\begin{array}{l}-0.003 \\
(0.720)\end{array}$ \\
\hline Horizon & $\begin{array}{l}-0.003 \\
(0.545)\end{array}$ & $\begin{array}{c}-0.019 * * \\
(0.024)\end{array}$ & $\begin{array}{l}-0.008 \\
(0.176)\end{array}$ & $\begin{array}{l}-0.022 * \\
(0.061)\end{array}$ \\
\hline Range & $\begin{array}{c}0.002 \\
(0.618)\end{array}$ & $\begin{array}{l}-0.005 \\
(0.523)\end{array}$ & $\begin{array}{l}-0.004 \\
(0.562)\end{array}$ & $\begin{array}{l}-0.015 \\
(0.297)\end{array}$ \\
\hline P_Month_Press_Cover & $\begin{array}{l}-0.010 \\
(0.423)\end{array}$ & $\begin{array}{l}-0.021 \\
(0.282)\end{array}$ & $\begin{array}{c}0.013 \\
(0.416)\end{array}$ & $\begin{array}{l}-0.020 \\
(0.505)\end{array}$ \\
\hline Instit_Own & $\begin{array}{l}-0.001 \\
(0.917)\end{array}$ & $\begin{array}{l}-0.009 \\
(0.436)\end{array}$ & $\begin{array}{l}-0.012 \\
(0.179)\end{array}$ & $\begin{array}{c}0.001 \\
(0.959)\end{array}$ \\
\hline Ln_MVE & $\begin{array}{c}0.001 \\
(0.687)\end{array}$ & $\begin{array}{l}-0.002 \\
(0.535)\end{array}$ & $\begin{array}{l}-0.001 \\
(0.605)\end{array}$ & $\begin{array}{l}-0.000 \\
(0.942)\end{array}$ \\
\hline BTM & $\begin{array}{c}0.000 \\
(0.945)\end{array}$ & $\begin{array}{c}0.002 \\
(0.894)\end{array}$ & $\begin{array}{l}-0.008 \\
(0.429)\end{array}$ & $\begin{array}{l}-0.003 \\
(0.860)\end{array}$ \\
\hline Ln_Follow & $\begin{array}{l}-0.001 \\
(0.705)\end{array}$ & $\begin{array}{c}0.002 \\
(0.768)\end{array}$ & $\begin{array}{l}-0.003 \\
(0.450)\end{array}$ & $\begin{array}{l}-0.003 \\
(0.749)\end{array}$ \\
\hline Dispersion & $\begin{array}{c}0.002 \\
(0.906)\end{array}$ & $\begin{array}{c}0.018 \\
(0.608)\end{array}$ & $\begin{array}{c}0.025 \\
(0.349)\end{array}$ & $\begin{array}{c}0.043 \\
(0.434)\end{array}$ \\
\hline Industry FE & Included & Included & Included & Included \\
\hline Year, Month, Day of Week FE & Included & Included & Included & Included \\
\hline Adj. $R^{2}$ & $4.3 \%$ & $4.2 \%$ & $10.0 \%$ & $8.0 \%$ \\
\hline No. Obs. & 1,856 & 1,864 & 768 & 771 \\
\hline $\begin{array}{l}\text { F-test p-value: Press_Cover }+ \\
\text { Top_Q_Guide_News*Press_Cover }=0\end{array}$ & $(0.294)$ & $(0.363)$ & $(0.137)$ & $(0.142)$ \\
\hline
\end{tabular}

This table contains the results of regressions examining price drift following press coverage of management earnings guidance.

See Appendix B for variable definitions. All continuous variables, except stock returns, are winsorized at the first and 99th percentiles to alleviate the effects of outliers on the analysis.

P-values are reported in parentheses based on t-statistics calculated using White's (1980) heteroscedasticity robust standard errors clustered by firm to control for dependency in the error terms (Petersen 2009; Gow et al. 2010).

Industry, year, month, and day of the week fixed effects are also included in the models (coefficients not reported). $*, * *, * * *$ indicate statistical significance at the $0.10,0.05$, and 0.01 levels, respectively, using a two-tailed test. 
TABLE 7

LONG-WINDOW RETURNS PORTFOLIOS

\begin{tabular}{|c|c|c|c|c|c|c|c|c|c|}
\hline & \multicolumn{4}{|c|}{ Abn_Return $(0,1)$} & \multicolumn{4}{|c|}{ Abn_Return $(2, \mathrm{t})$} & \multirow{2}{*}{$\begin{array}{c}\text { Guide_News } \\
\text { Difference } \\
\text { P-value }\end{array}$} \\
\hline & Covered & $\begin{array}{c}\text { Non- } \\
\text { Covered }\end{array}$ & Diff. & P-value & Covered & $\begin{array}{c}\text { Non- } \\
\text { Covered }\end{array}$ & Diff. & P-value & \\
\hline \multicolumn{10}{|c|}{ Propensity-Score Matched Sample of Stand-Alone Guidance } \\
\hline \multicolumn{10}{|l|}{$\mathrm{t}=10$} \\
\hline Low $(0, t)$ Quintile & -0.121 & -0.105 & -0.015 & $(0.026)$ & -0.034 & -0.050 & 0.016 & $(0.001)$ & $(0.474)$ \\
\hline High $(0, t)$ Quintile & 0.069 & 0.053 & 0.016 & $(0.001)$ & 0.041 & 0.056 & -0.015 & $(0.001)$ & $(0.462)$ \\
\hline \multicolumn{10}{|l|}{$\mathrm{t}=30$} \\
\hline Low $(0, t)$ Quintile & -0.102 & -0.087 & -0.015 & $(0.042)$ & -0.083 & -0.096 & 0.013 & $(0.047)$ & $(0.729)$ \\
\hline High $(0, t)$ Quintile & 0.057 & 0.036 & 0.021 & $(0.001)$ & 0.096 & 0.121 & -0.025 & $(0.001)$ & $(0.112)$ \\
\hline \multicolumn{10}{|c|}{ Within-Firm Matched Sample of Stand-Alone Guidance } \\
\hline \multicolumn{10}{|l|}{$\mathrm{t}=10$} \\
\hline Low $(0, t)$ Quintile & -0.106 & -0.074 & -0.031 & $(0.001)$ & -0.027 & -0.048 & $\mathbf{0 . 0 2 0}$ & $(0.003)$ & $(0.013)$ \\
\hline High $(0, t)$ Quintile & 0.080 & 0.055 & 0.025 & $(0.002)$ & 0.035 & 0.054 & -0.019 & $(0.004)$ & $(0.167)$ \\
\hline \multicolumn{10}{|l|}{$\mathrm{t}=30$} \\
\hline Low $(0, t)$ Quintile & -0.084 & -0.057 & -0.027 & $(0.007)$ & -0.085 & -0.103 & 0.017 & $(0.088)$ & $(0.061)$ \\
\hline High $(0, t)$ Quintile & 0.066 & 0.040 & 0.025 & $(0.002)$ & 0.099 & 0.115 & -0.016 & $(0.088)$ & $(0.720)$ \\
\hline
\end{tabular}

This table presents mean values of stock returns over different time windows beginning the day guidance was announced. Firms are sorted into quintiles based on total returns over the period, and mean returns are presented for the lowest and highest return quintiles. Results are shown for both the propensity-score matched sample (4,998 observations) and the within-firm matched sample (2,092 observations) of stand-alone guidance.

Differences in bold are significant at the $\alpha=0.05$ level, using two-tailed $t$-tests of means. 
TABLE 8

MARKET REACTION TO PRESS COVERAGE OF MANAGEMENT EARNINGS GUIDANCE COMPARISON OF STAND-ALONE AND BUNDLED GUIDANCE

\begin{tabular}{|c|c|c|c|}
\hline $\begin{array}{l}\text { Dependent variable: } \\
\text { Abn_Return }(0,1)\end{array}$ & $\begin{array}{c}\text { Full Sample of } \\
\text { Stand-Alone Guidance }\end{array}$ & $\begin{array}{c}\text { Full Sample of } \\
\text { Bundled Guidance }\end{array}$ & Difference \\
\hline Guide_News & $\begin{array}{c}2.290 * * * \\
(0.001)\end{array}$ & $\begin{array}{c}3.137 * * * \\
(0.001)\end{array}$ & \\
\hline Press_Cover & $\begin{array}{c}0.013 * * * \\
(0.001)\end{array}$ & $\begin{array}{l}0.002 * * \\
(0.016)\end{array}$ & \\
\hline Guide_News*Press_Cover & $\begin{array}{c}2.212^{* * *} \\
(0.001)\end{array}$ & $\begin{array}{c}0.542 * * * \\
(0.001)\end{array}$ & $\begin{array}{c}1.670 * * * \\
(0.001)\end{array}$ \\
\hline Fraction & $\begin{array}{c}-0.044 * * * \\
(0.001)\end{array}$ & $\begin{array}{l}-0.002 \\
(0.168)\end{array}$ & \\
\hline Guide_Reputation & $\begin{array}{l}0.003 * \\
(0.088)\end{array}$ & $\begin{array}{c}-0.003 * * * \\
(0.001)\end{array}$ & \\
\hline Horizon & $\begin{array}{l}0.006^{* *} \\
(0.035)\end{array}$ & $\begin{array}{c}0.000 \\
(0.745)\end{array}$ & \\
\hline Range & $\begin{array}{l}-0.004 \\
(0.124)\end{array}$ & $\begin{array}{l}-0.001 \\
(0.366)\end{array}$ & \\
\hline P_Month_Press_Cover & $\begin{array}{c}0.002 \\
(0.798)\end{array}$ & $\begin{array}{c}0.005^{*} \\
(0.086)\end{array}$ & \\
\hline Instit_Own & $\begin{array}{l}-0.001 \\
(0.874)\end{array}$ & $\begin{array}{c}0.001 \\
(0.536)\end{array}$ & \\
\hline Ln_MVE & $\begin{array}{l}0.002 * \\
(0.058)\end{array}$ & $\begin{array}{l}-0.001 * \\
(0.052)\end{array}$ & \\
\hline BTM & $\begin{array}{c}0.014 * * * \\
(0.001)\end{array}$ & $\begin{array}{c}0.008 * * * \\
(0.001)\end{array}$ & \\
\hline Ln_Follow & $\begin{array}{l}-0.001 \\
(0.777)\end{array}$ & $\begin{array}{l}-0.001 \\
(0.234)\end{array}$ & \\
\hline Dispersion & $\begin{array}{c}0.010 \\
(0.451)\end{array}$ & $\begin{array}{c}0.021 * * * \\
(0.002)\end{array}$ & \\
\hline Industry FE & Included & Included & \\
\hline Year, Month, Day of Week FE & Included & Included & \\
\hline Adj. $\mathrm{R}^{2}$ & $14.6 \%$ & $6.2 \%$ & \\
\hline No. Obs. & 9,286 & 49,774 & \\
\hline
\end{tabular}

This table contains the results of regressions examining the market reaction to press coverage of management earnings guidance across samples of stand-alone and bundled guidance.

See Appendix B for variable definitions. All continuous variables, except stock returns, are winsorized at the first and 99th percentiles to alleviate the effects of outliers on the analysis.

P-values are reported in parentheses based on t-statistics calculated using White's (1980) heteroscedasticity robust standard errors clustered by firm to control for dependency in the error terms (Petersen 2009; Gow et al. 2010). Industry, year, month, and day of the week fixed effects are also included in the models (coefficients not reported).

$*, * *, * * *$ indicate statistical significance at the $0.10,0.05$, and 0.01 levels, respectively, using a two-tailed test. 
TABLE 9

HECKMAN SELECTION MODEL RESULTS

\begin{tabular}{llcc}
\hline $\begin{array}{l}\text { Dependent } \\
\text { Variable: }\end{array}$ & $\begin{array}{l}\text { Independent Variables } \\
\text { of Interest: }\end{array}$ & $\begin{array}{c}\text { Full Sample of } \\
\text { Stand-Alone Guidance } \\
(9,286 \text { obs })\end{array}$ & $\begin{array}{c}\text { Full Sample of } \\
\text { All Guidance } \\
(66,598 \text { obs })\end{array}$ \\
\hline & Guide_News*Press_Cover & $2.262^{* * *}$ & $1.513^{* * * *}$ \\
& Inv_Mills & $(0.001)$ & $(0.001)$ \\
Abn_Return(0,1) & Guide_News*Inv_Mills & $-0.011^{* *}$ & $-0.007^{* * *}$ \\
(Table 5, Panel A) & & $(0.014)$ & $(0.001)$ \\
& & 0.430 & $2.003^{* * *}$ \\
& & $(0.501)$ & $(0.001)$ \\
& Abs_Guide_News*Press_Cover & $5.889^{* * *}$ & $4.311^{* * *}$ \\
Fraction & & $(0.001)$ & $(0.001)$ \\
(Table 5, Panel B) & Inv_Mills & $-0.145^{* * *}$ & $-0.120^{* * *}$ \\
& & $(0.001)$ & $(0.001)$ \\
& Abs_Guide_News*Inv_Mills & $8.760^{* * *}$ & $7.315^{* * *}$ \\
& & $(0.001)$ & $(0.001)$ \\
\end{tabular}

This table contains the results of regressions examining the market reaction to press coverage of management earnings guidance using a Heckman two-stage selection model.

For the sake of parsimony, only the coefficients and p-values of the independent variables of interest in each test are presented.

Inv_Mills is the inverse mills ratio from the Heckman two-stage selection model. See Appendix B for all other variable definitions. All continuous variables, except stock returns, are winsorized at the first and 99th percentiles to alleviate the effects of outliers on the analysis.

P-values are reported in parentheses based on t-statistics calculated using White's (1980) heteroscedasticity robust standard errors clustered by firm to control for dependency in the error terms (Petersen 2009; Gow et al. 2010). Industry, year, month, and day of the week fixed effects are also included in the models (coefficients not reported). $*, * * * * *$ indicate statistical significance at the $0.10,0.05$, and 0.01 levels, respectively, using a two-tailed test. 


\section{APPENDIX B}

\section{VARIABLE DEFINITIONS}

\section{Press Coverage Variables}

Press_Cover

Press_Cover_\%

Other Press Cover

Other_Ind_Press_Cover

P_Guide_Press_Cover

P_Month_Press_Cover

Other Variables

Abn_Return(0,1)

Abn_Return(0,t)

Abn_Return(2,t)

Abs_Abn_Return(0,1)
Abs_Guide_News
After_Hours
Annual

Bad_Guide_News

BTM

Bundled

Dispersion

Follow

Fraction

Guide_News

Guide_Reputation

Horizon

Instit Own

Inv_Mills

Ln_Follow

Ln_MVE
$=$ an indicator variable equal to one if the guidance received press coverage in the $D J$ Newswires on the day the guidance is announced, and zero otherwise.

$=$ the percentage of the firm's guidance that received press coverage in the DJ Newswires during the sample period.

= the number of other firms with an earnings or guidance-related press article in the $D J$ Newswires or WSJ on the day the guidance is announced, in hundreds.

= the number of other firms in the same industry that received press coverage in the $D J$ Newswires or WSJ on the day the guidance is announced, in hundreds.

$=$ an indicator variable equal to one if the firm's most recent prior guidance received press coverage in the DJ Newswires, and zero otherwise.

$=$ the number of days during the 30 day period ending on the day prior to the guidance announcement that the firm received press coverage in the DJ Newswires or WSJ, divided by 30 .

$=$ the raw buy-and-hold stock return over the two day period beginning the day the guidance is announced, minus the return to a benchmark portfolio formed based on size, book-to-market, and momentum over the same two day period.

$=$ the raw buy-and-hold stock return over the time period beginning the day the guidance is announced and ending on day $t$ (where $t=10$ or 30 ), minus the return to a benchmark portfolio formed based on size, book-to-market, and momentum over the same time period.

$=$ the raw buy-and-hold stock return over the time period beginning two days after the guidance is announced and ending on day $\mathrm{t}$ (where $\mathrm{t}=10$ or 30 ), minus the return to a benchmark portfolio formed based on size, book-to-market, and momentum over the same time period.

$=$ the absolute value of $A b n \_\operatorname{Return}(0,1)$.

$=$ the absolute value of Guide_News.

$=$ an indicator variable equal to one if the guidance is issued after the closing of stock market trading hours, and zero otherwise.

$=$ an indicator variable equal to one if the guidance is for annual earnings, and zero if the guidance is for quarterly earnings.

$=$ an indicator variable equal to one if Guide_News $<0$, and zero otherwise.

$=$ the book-to-market ratio as of the end of the most recent quarter.

$=$ an indicator variable equal to one if the guidance is issued within 2 days of an earnings announcement date, and zero otherwise.

$=$ the standard deviation of the most recent consensus analyst forecast.

$=$ the number of analysts following the firm.

$=$ the number of analysts who revise their forecasts during the two day period beginning the day the guidance is announced, scaled by Follow.

$=$ the guidance minus the consensus analyst forecast, scaled by stock price as of two days prior to the day the guidance is announced, where the consensus analyst forecast is calculated as the mean of the most recent forecast issued by each individual analyst during the 90 day period ending three days prior to the guidance announcement. For guidance that is bundled with an earnings announcement, Guide_News is calculated using the conditional expectations model developed in Rogers and Van Buskirk (2012).

$=$ the average relative accuracy of the firm's guidance issued during the prior 3 years, where relative accuracy is equal to 1,0 , and -1 , respectively, if the absolute value of the consensus analyst forecast error prior to the guidance is greater than, equal to, or less than the absolute value of the guidance error.

$=$ the number of days between the day the guidance is announced and the end of the fiscal period, divided by 365 .

$=$ the number of shares held by institutional investors, scaled by total shares outstanding.

$=$ the inverse mills ratio obtained from the Heckman two-stage selection model.

$=$ the natural logarithm of Follow.

$=$ the natural logarithm of market value of equity. 
Loss

Meet_Beat_Hist

Multiple

P_Month_Abn_Ret

P_Month_Turn

P_Month_Ret_Vol

Q_ERC

Q_Guide_News

Range

Revision

ROA

SP1500

Top_Q_Guide_News
$=$ an indicator variable equal to one if net income before extraordinary items was $<0$ in the most recent quarter, and zero otherwise.

$=$ the proportion of the prior four quarters that the firm met or exceeded analysts' earnings expectations.

$=$ an indicator variable equal to one if the firm issued guidance for more than one period on the same day, and zero otherwise.

$=$ the raw buy-and-hold stock return over the 30 day period ending on the day prior to the guidance announcement, minus the return to a benchmark portfolio formed based on size, book-to-market, and momentum over the same 30 day period.

$=$ prior stock turnover, calculated as the average of daily trading volume scaled by total number of shares outstanding over the 30 day period ending on the day prior to the guidance announcement.

$=$ prior stock return volatility, calculated as the standard deviation of the firm's raw stock returns over the 30 day period ending on the day prior to the guidance announcement.

$=$ the absolute value of abnormal stock returns over the two day period beginning on the day of the firm's most recent quarterly earnings announcement, divided by the absolute value of the earnings surprise, ranked into quintiles by year.

$=$ the quintile ranking of Guide_News by year.

$=$ an indicator variable equal to one if the guidance is in the form of a range, and zero if the guidance is a point forecast.

$=$ the difference between the post-guidance consensus analyst forecast and the consensus analyst forecast prior to the guidance, scaled by stock price as of two days prior to the guidance announcement, where the post-guidance consensus analyst forecast is calculated as the mean of the first forecast issued by each individual analyst during the 30 day period beginning the day the guidance is announced.

$=$ return on assets, calculated as net income before extraordinary items divided by total assets.

$=$ an indicator variable equal to one if the firm is in the S\&P 1500 stock index as of the guidance announcement date, and zero otherwise.

$=$ an indicator variable equal to one for the highest quintile of $Q \_$Guide_News, and zero otherwise. 